\title{
Cities, value chains, and dairy production in Ethiopia
}

Joachim Vandercasteelen, Bart Minten, and Seneshaw Tamru 


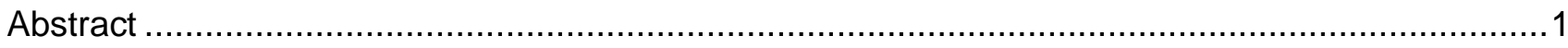

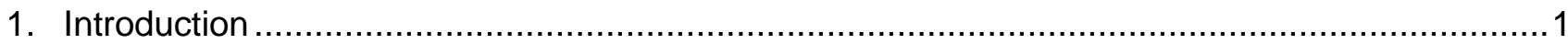

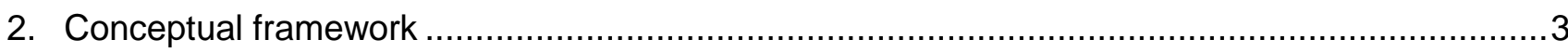

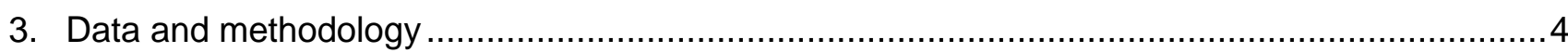

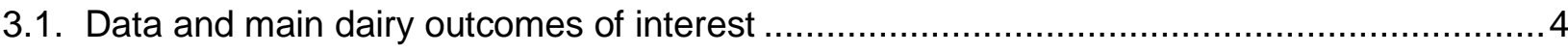

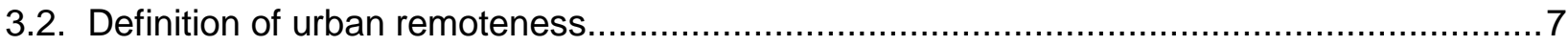

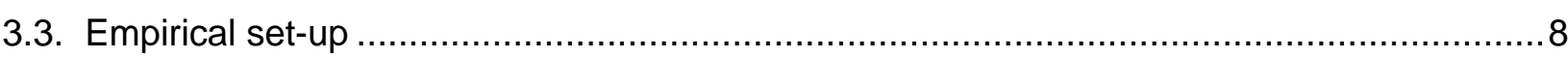

4. Spatial variation in milk production and productivity .................................................. 10

5. Spatial variation in dairy farmers' household economy ................................................... 12

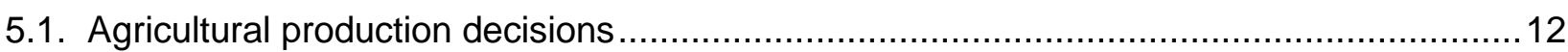

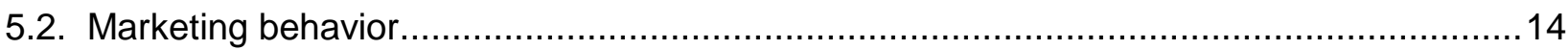

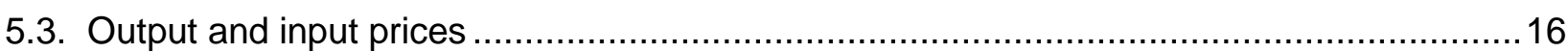

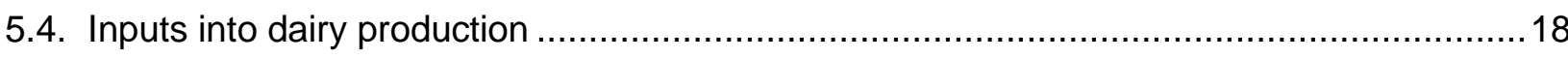

5.5. Access to the value chain, commercial buyers and services offered .............................20

6. Mechanisms: Spatial variation in prices and market access ................................................21

6.1. Direct effect of travel time on prices and market access .......................................... 22

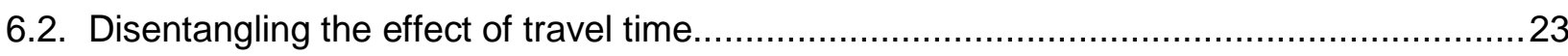

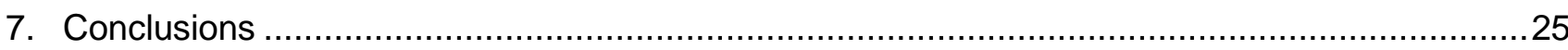

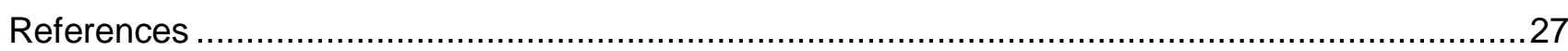

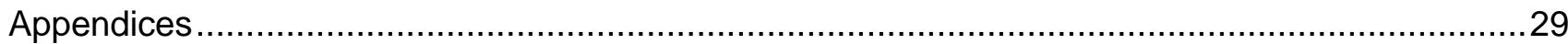

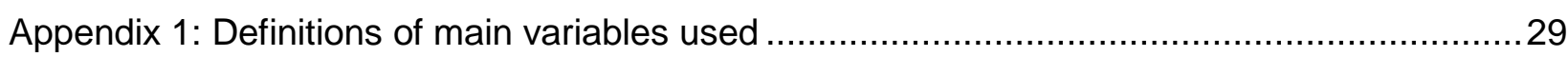

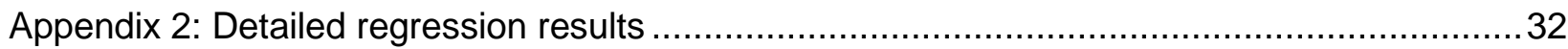

\section{TABLES}

Table 3.1: First stage regression to instrument travel time to Addis Ababa with a measure of time to

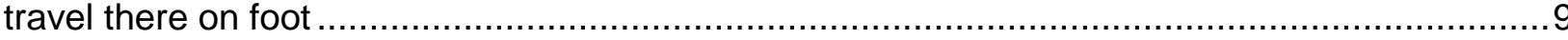

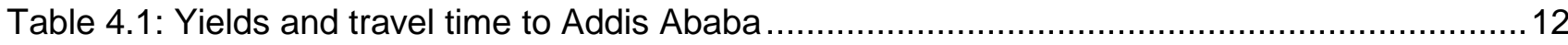

Table 6.1: Dairy prices, input application, value chain access, and travel time to Addis Ababa.......22

Table 6.2: Milk productivity and travel time to Addis Ababa, with increasing number of controls ..... 24

\section{FIGURES}

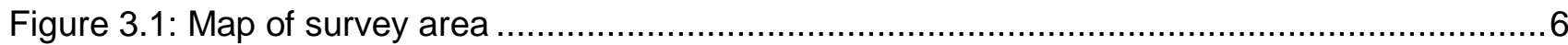

Figure 4.1: Milk production and productivity, by travel time to Addis Ababa ...............................11

Figure 5.1: Production decisions, by travel time to Addis Ababa ...........................................

Figure 5.2: Marketing decisions and sales values, by travel time to Addis Ababa ....................... 15

Figure 5.3: Milk and processed dairy sales characteristics, by travel time to Addis Ababa............. 16

Figure 5.4: Dairy output and input prices, by travel time to Addis Ababa.................................. 17

Figure 5.5: Cow herd size and composition, by travel time to Addis Ababa.................................. 18

Figure 5.6: Inputs into dairy production, by travel time to Addis Ababa .................................. 19

Figure 5.7: Access to dairy buyers and services offered, by travel time to Addis Ababa ...............21 


\section{ABSTRACT}

This paper explores the spatial heterogeneity in dairy production in the highland production area around the capital of Ethiopia, Addis Ababa. We look at how urban proximity - defined as the travel time from the farm to the central market of Addis Ababa - affects the production decisions of Ethiopian dairy farmers. We sampled 870 households from the major rural production zones around Addis Ababa, where villages were stratified according to their distance to Addis Ababa. Using an instrumental variable approach, we find evidence of strong spatial heterogeneity in dairy milk productivity in Ethiopia. With each additional hour of travel time, the milk productivity per cow is reduced by almost 1 liter per day, a reduction by 26 percent on average. This spatial heterogeneity in milk productivity reflects a pronounced spatial variation in dairy production decisions (producing liquid milk or processed dairy products), the application of modern inputs, and marketing. When trying to disentangle the mechanisms through which urban proximity affects dairy productivity, we show that the effect of travel time mainly runs through farmers' inclusion into 'modern' value chains and more specifically through their access to commercial milk buyers. This finding holds when we control for prices, indicating that access to commercial value chains are an important determinant of dairy productivity. However, as only a limited number of farmers now have access to such value chains in these settings, measures to make dairy value chains more inclusive to remote farmers can have important economic development benefits for them.

Keywords: Urban proximity, Value chains, Dairy productivity, Ethiopia, Sub Saharan Africa

\section{INTRODUCTION}

Food systems in Sub Saharan Africa (SSA) have undergone rapid changes in the last decades (AGRA 2019). On the one hand, food procurement systems are changing with the emergence of modern supply chains that are characterized by more vertical coordination and with increased concentration in retail and trading. On the other hand, increased consumers' insistence on food and workers' safety measures are giving rise to product standards and certification schemes, which reinforces the need for close cooperation between actors throughout agricultural value chains. As such, modern value chains for agricultural products are on the rise - but from a low base - in SSA; and when farmers have access to them, it has been shown that such value chains could provide farmers the necessary incentives to modernize and intensify their agricultural production practices (Swinnen and Kuijpers 2018; Christiaensen and Vandercasteelen 2019).

Value chain growth is accelerating because of rapid urbanization in SSA and the associated increased urban demand for agricultural products. The African continent now has the highest urban population growth rate of all continents. The urbanization process in resource dependent countries in Africa is characterized as being associated with the rise of mostly consumption cities (Gollin et al. 2016). Given that urban incomes in Africa are generally higher (compared to rural incomes), and increasing over time, urban households are spending more and more on food in absolute terms. But urban households also are shifting their food consumption patterns towards protein- or calorie-rich foods. Dairy products are a good example of agricultural products that have seen and will continue to see substantial increases in urban demand, especially given high-income elasticities for such products. According to OECD and FAO (2016), the demand for dairy products in SSA increased by 1.8 percent per year in the last decade. This growth rate is expected to accelerate to an annual rate of 2.6 percent in the coming decade, mostly coming from increased urban demand. Thus, this increased demand for dairy products may provide rural dairy producers with needed incentives and market opportunities to expand, intensify, and modernize their production. 
If urban demand is an important driver of modernizing agricultural production, then the location of farmers with respect to large centers of urban demand determines how well farmers can reap the potential benefits from these growing markets. The distance to urban centers, as measured by travel time, has indeed been shown to be a significant predictor of modernization and intensification of agricultural production of farmers in the rural hinterland around large urban centers. For example, Vandercasteelen et al. (2018a) show that for the production of teff, the largest cash crop in Ethiopia, farmers located closer to the capital use significantly more improved seeds and chemical fertilizer, receive higher prices for their teff output, and ultimately have higher productivity levels. Damania et al. (2016) similarly show that in Nigeria, transport costs are an important determinant for the adoption of modern inputs in crop production, and they subsequently strongly determine farm revenues. Steinhübel (2018) shows that proximity to secondary towns (not necessarily large urban centers) and road infrastructure increase the uptake of modern inputs in Bangalore, India. ${ }^{1}$

While most of the theoretical and empirical work on agricultural production and intensification looks at crop production, spatial theories have rarely been applied to dairy production. Yet, dairy production provides an interesting study of how access to (growing) urban demand affects production outcomes at the farm level. Moreover, dairy consumption has important health and nutrition related outcomes. Given the perishability of milk (in the absence of a functioning cold chain, as often is the case in Africa), proximity with respect to urban centers determines the importance of dairy production within the agricultural sector, in line with the predictions of the Von Thünen (1826) model. More importantly, within the dairy sector, location is also likely to determine specialization into different dairy products (raw versus processed milk), an aspect not seen for storable cereals. ${ }^{2}$ This perishability also imposes the need for tighter coordination between different actors (horizontally and vertically) in dairy value chains. Hence, in responding to increased market opportunities, value chain development is likely to happen more quickly in the dairy sector than in most other agricultural sub-sectors (see, for example, Janssen and Swinnen (2018) for India, Lie et al. (2018) for Nicaragua, and Kilelu et al. (2016) for Kenya). Finally, Ethiopia provides an interesting setting in which to analyze market access induced changes in the dairy sector, because it has the largest herd size of livestock in SSA, and the livestock sector, therefore, is inherently very important in the development of the agricultural sector and the rural economy overall. Moreover, Ethiopia has been investing substantially in its road infrastructure to improve connectivity and market access.

There is, however, limited evidence on how urban proximity affects farm productivity decisions in the dairy sector. In order to address this research question, this paper analyses the effect of urban proximity - defined here as travel time from the farm to the major urban area - on the production decisions and outcomes of dairy farmers. To this end, we use data on dairy farmers located in the rural hinterland of the capital Addis Ababa, collected though a stratified sampling procedure based on distance to the city. Villages were (randomly) sampled according to their distance to the capital and their access to a main road. As such, we fully exploit the spatial heterogeneity in dairy production in the commercial production area of Ethiopia. The data at hand is from a cross-sectional data set collected from 870 dairy farmers in 2018 in the two main commercial production zones around the capital. There might, however, be potential endogeneity issues in the analysis because of reverse causality and omitted variable bias in the relationship between urban proximity and decisions in dairy farming. To overcome these problems, we apply an instrumental variable

\footnotetext{
${ }^{1}$ These studies carefully measure travel distances and account for potential endogeneity issues. Other studies have looked indirectly at the productivity effects of farmers' location with respect to large urban centers, by looking at physical travel distances (e.g., Amare and Shiferaw 2017) or by interacting it with binary market access indicators (e.g., limi et al. 2018). There is also the extensive literature on the importance of roads for the modernization of the agricultural sector in Africa (Dorosh et al. 2012; Berg et al. 2018)

${ }^{2}$ While many dairy products are considered perishable and liquid milk certainly is, there are processed dairy products that are less perishable. Hence, while distance would affect the type of agricultural production (cereal versus diary), it will also affect the type of dairy product produced.
} 
approach similar to Damania et al. (2016) and Vandercasteelen et al. (2018b). We use the 'natural path' cost of how long it would take a farmer to walk to an urban center to instrument for the road network-based measurement of travel time. ${ }^{3}$ Hence, this paper also makes an important methodological contribution by combining georeferenced household level survey data with publicly available data from geographical information systems.

We find strong evidence of spatial heterogeneity in milk productivity and other dairy production outcomes. For each additional hour of travel time to Addis Ababa that farmers face, their milk productivity is reduced by 0.8 liter per cow per day, or 26 percent, based on the average productivity levels in our sample. This productivity pattern is reflected in the differential decisions dairy producers take and the outcomes they achieve. Farmers that are closer to the capital are more likely to specialize in liquid milk production (as opposed to processed dairy products), are more likely to sell liquid milk, and apply higher amounts of modern inputs into dairy production. The paper further tries to disentangle the mechanisms through which urban proximity affects dairy productivity. Traditional spatial location theories focus on transaction costs and differential consumer demand, which is reflected by the prices that farmers face for their inputs and outputs in dairy production. However, when controlling for such output price effects, we show that the dominant effect through which travel time affects dairy producers in Ethiopia is their access to modern value chains, and, more specifically, farmers' access to commercial buyers of fresh liquid milk, i.e., milk processing companies or collectors that serve modern processing companies.

This paper makes several other contributions to the existing literature. While there is a substantial literature that has linked (improved) access to market and road infrastructure with improved well-being for households in rural areas of developing countries (Stifel and Minten 2017; Berg et al. 2018; Nakamura et al. 2019), most of this research remains silent on the mechanisms through which market access improves household outcomes. This paper shows that for agricultural households located close to the capital of Ethiopia, access to modern value chains is an important pathway to higher agricultural productivity levels and, hence, to transformation of the agricultural sector. The paper thus provides empirical evidence to support the conceptual foundations that access to value chains leads to technology transfer and productivity increases (Swinnen and Kuijpers 2018). Furthermore, this paper is among the first to empirically assess the effect of urban proximity on factors underlying the modernization of the dairy sector in Ethiopia or elsewhere. In doing so, it provides a better understanding of how the expansion of the dairy sector in developing countries can contribute to achieving other development objectives such as, for example, improved child nutrition (Abay and Hirvonen 2017; Hirvonen et al. 2017; Vandevelde and D'Haene 2019).

\section{CONCEPTUAL FRAMEWORK}

How does the location of farming households with respect to the largest urban center affect their agricultural production decisions in general and dairy production specifically?

The literature on spatial location theory in agriculture predicts the type of agricultural products that farmers produce based on their distance to the urban center. Building upon von Thünen's model of the isolated state, the urban center is the fixed source of demand for agricultural products, which results in concentric circles of production. Distance captures the transaction costs to transport agricultural goods from the farm to the urban center, which highly depend on their perishability. The model predicts that perishable and difficult to transport products, e.g., vegetables, are produced close to the urban center, while cereal production and grazing lands become more important with increasing distance. The interpretation can be thought about as an iceberg model (e.g., Samuelson

${ }^{3}$ While we are not the first to apply such instrumental variable approach, we make use of new data on road infrastructure in Ethiopia and apply an improved methodology to construct the cost path following the approach of Weiss et al. (2018). 
1952), i.e., the net price farmers receive from the (fixed) urban price decreases due to the cost of transportation, cooling, etc. At some distance from the urban center it becomes unprofitable to produce perishable goods, and farmers switch to cereal production, etc. The spatial location theory in agriculture can be linked with a more general model of economic location theory that predicts agricultural activities to be less likely performed close to urban centers (Davis et al. 2017; Fafchamps and Shilpi 2003).

Theories describing the evolution of farming systems in developing countries also explicitly consider the role of the spatial location of the farm. Binswanger and Pingali (1984) identified market access as an important driver for farm intensification, besides the necessity forces that arise from increased population pressure (Boserup 1965). Better market access - either through the increased availability of urban or foreign markets or access to roads to enter these markets - provides farmers improved trading opportunities and, hence, the incentives to invest in their farming systems towards higher intensity and higher productivity systems. Improved market access means that farmers receive a higher effective price - because of lower transaction costs or higher prices in urban markets - and farmers located around cities with different population sizes will receive different prices for their agricultural products because of these demand effects. Binswanger and Savastano (2017) estimate the impact of market access, proxied by an urban gravity measure based on (travel time weighted) nighttime light emission, on agricultural intensification in several African countries. They find that increased urban demand has led to increased cropping intensity, but had little effect on input intensification. Other recent work has looked at whether the size of the city around which farmers are located matters for their intensification outcomes (e.g., Vandercasteelen et al. 2018b).

Finally, urban proximity affects agricultural production through effects other than price incentives and transaction costs. Farmers' production decisions will also be determined by their access to inputs and technologies, or more broadly, how well farmers are connected with the value chain that is formally or informally built around the agricultural product. ${ }^{4} \mathrm{~A}$ formal model of technology adoption in agricultural value chains, and under which conditions it is more likely to emerge, is derived by Kuijpers and Swinnen (2017). Evidence from developing countries, however, is scant, but recent empirical work finds that factors determining farmers' access to markets within local value chains, including their geographical proximity, play important role in stimulating agricultural intensification. For example, Vandercasteelen et al. (2018a) find that, after controlling for price effects, urban proximity has a direct effect on staple crop production that seems to run through farmers' access to information, network effects, and input markets.

\section{DATA AND METHODOLOGY}

\subsection{Data and main dairy outcomes of interest}

This paper explores spatial variation in Ethiopian dairy production by using household level data that was collected as part of a stacked survey data collection process on the entire value chain that provides dairy products to consumers in the Ethiopian capital, Addis Ababa. ${ }^{5}$ We use data collected between January and February 2018 from 870 dairy producing households sampled at different distances from Addis Ababa. All these households were interviewed using a detailed questionnaire on dairy production, household and child (dairy) consumption, and other measures of welfare. In addition, a community level questionnaire was administered to leaders and elders who are engaged

\footnotetext{
${ }^{4}$ Closer coordination between different actors within the value chain of an agricultural product is considered to reduce transaction costs and allows for increased value addition. In this way, value chains can be considered as institutional arrangements to reduce the effect of transaction costs and urban remoteness on production outcomes.

${ }^{5}$ See Minten et al. (2018) for a detailed description of the stacked value chain data collection on Dairy in Ethiopia.
} 
in dairy production (both small and large scale) in each village surveyed about village level trends in dairy production and agricultural input and output prices.

Of our analytical sample, 589 dairy producers are located in the two major rural dairy production zones around Addis Ababa, i.e., North and West Shewa. To construct the sampling scheme in these rural areas, all woredas (the district-level administrative unit) in the two production zones were ranked according to their remoteness from Addis Ababa, as measured by the travel time using the road network. The ranked woredas were divided in quartiles. The number of woredas retained from each quartile for the survey was proportional to the number of cows. In the closest quartile, four woredas were randomly selected, while in the remaining three quartiles, two woredas were selected. Next, three kebeles (the sub-district administrative unit) were selected randomly in each of these woredas, depending on their location with respect to the main road. In the two closest woreda quartiles, two kebeles located close to the main road, and one kebele without access to the road were chosen; while in the furthest two woreda quartiles, three kebeles were randomly selected without taking into account road access. In each of the selected kebeles, a census was conducted on households having at least one cow in milk production. Ten households were then randomly selected that had one or two cows in milk, and another ten households were randomly selected that had three or more cows in milk.

We also use the data collected on dairy producers located in the 'Oromia Special Zone surrounding Finfinne', which is the zone surrounding Addis Ababa. Following a similar sampling strategy as for the rural zones, 241 farmers were interviewed in this suburban area. First, three woredas were selected with a probability of selection proportional to their level of dairy production. Four kebeles then were randomly selected in each selected woreda - three kebeles located close to the main road and one kebele with poor road access. In each kebele selected, a census was done of active dairy producing households. We randomly selected ten households with one or two cows in milk and ten households with three or more cows in milk in each selected kebele.

Finally, a census of dairy producing farms was conducted in Addis Ababa for the purpose of a commercial dairy farm survey (data not used here). From this census, 30 small-scale dairy producing households that have one or two cows in milk were randomly selected to be interviewed for the household survey. These different groups of households are displayed in Figure 3.1.

These dairy households produce raw milk that can be retained as liquid milk or can be processed by the household themselves into yoghurt, butter, baadu (cottage cheese), or harder cheese, depending on the stage and length of fermentation. In this paper, we adopt the following terminology: 'raw milk' refers to the total amount of dairy milk produced by the cows owned by the household; 'liquid milk' is the amount of raw milk that is used as liquid milk as end product for consumption or marketing purpose; and 'processed dairy products' is the amount of self-processed dairy products in milk equivalents. To calculate the latter, we apply local conversion rates that describe the amount of milk in liters that is needed to produce a kilogram of processed dairy. ${ }^{6}$ As such, 'raw milk' is equal to the sum of 'liquid milk' and 'processed dairy products'. In both cases, raw milk refers thus to raw milk produced by cows, and not pasteurized milk that might be found in supermarkets.

${ }^{6} 10$ liters of milk gives approximately $7.5 \mathrm{kgs}$ of cheese or $0.5 \mathrm{kgs}$ of butter 


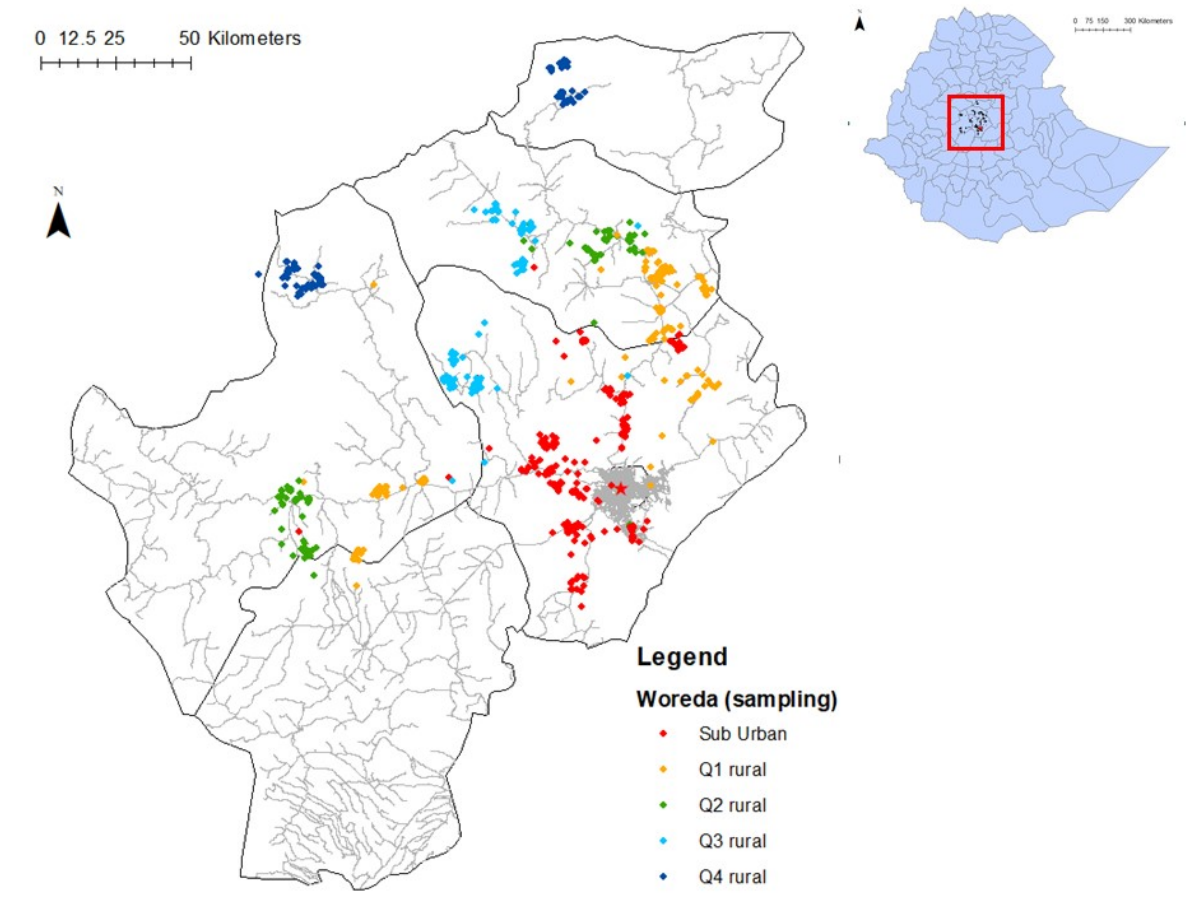

Source: Authors.

Milk productivity is the main dairy indicator of interest. Milk production is defined as the quantity of raw liquid milk produced by all cows owned and in production by the household, expressed in liter per day. This recall data was collected for intervals of two months for the previous year starting from January 2017, providing six observations for each household. We take the average value of these two monthly recall periods to cancel out the effect of seasonality, which surprisingly is not very strong in our data. To calculate total milk production over a longer time period, we multiply the milk daily production with the amount of days in a month or in a year that the household's cows were active in milk production. We measure milk productivity as the daily milk production per cow, which is the ratio of milk production over the total number of cows (local and crossbred) in production within the two-month recall period.

Many additional dairy outcome indicators are considered in the empirical analysis. An overview of the different indicators with their definitions is provided in Appendix 1. Price data were collected in the dairy marketing sections of the survey questionnaire, where each household had to list all sales transactions of liquid milk and processed dairy products, specifying the quantity sold, prices, type of buyer, location of sales, terms of payment, etc. When multiple transactions occurred, we take the average value (or the maximum for categorical variables) over the different transactions. We further have a separate section on market prices over the last past 12 months, including the last (hence, current) price, which is used for households that have no dairy transaction data. As butter is more often sold, we have the self-reported price of butter for each household individually.

For remote households, however, price data is often missing for liquid milk and cheese, as these dairy products are not often sold in remote areas. To address missing values, we first replace the missing values of individual households with the village level price of dairy products in the last month (collected in the community questionnaire). Nonetheless, there are remote villages where no dairy producer sold any liquid milk or cheese, and hence we have no price information. To avoid these households dropping out from the empirical analysis (when we control for prices), we impute prices from a regression of self-reported milk or cheese price on general dairy production and marketing characteristics, as well as household characteristics, and woreda fixed effects. These 
imputed prices correlate strongly with actual prices ( 0.85 and 0.70 for households with non-missing prices for milk and cheese, respectively) and are used in the regression analysis. ${ }^{7}$

Data on the size, composition value, and change in stock of the household's cattle herd was collected for different types of cows, differentiated by crossbred, i.e., any animal with exotic blood, or local cattle. Data on feeding and watering inputs into dairy production were collected at the level of crossbred and local cattle, with a differentiation between whether the cows were in milk production or not. Transaction data (quantity, price, and seller characteristics) was also collected on different dairy inputs, such as fodder and crop residues, as well as industrial feed products. Finally, detailed data on breeding, artificial insemination, and animal health was collected at household level. Dairy input indicators on usage or expenditure that were used in the analysis are household level averages or totals. The data collected on land ownership and crop cultivation, other livestock income, and non-crop and non-dairy income allows the calculation of total income at household level, as well as the contribution of each of the different income sources to total income. All variables expressing expenditures or incomes are converted into USD. ${ }^{8}$ Finally, a whole set of different household and farmer characteristics, e.g., assets, credit, etc., was collected to serve as control variables in the empirical analysis.

\subsection{Definition of urban remoteness}

We define urban remoteness as the travel time from the farm of each household to Addis Ababa, which we assume to be the central market place for liquid milk. This travel time (in hours) using the existing road network in Ethiopia is constructed as the combination of two travel times. ${ }^{9}$ First, we measure the walking time from the farm to the nearest road segment that is on the digital map used for the analysis. Second, we calculate the travel time from the household's nearest road segment to Addis Ababa using the existing road network, assuming that traders transport their goods using motorized vehicles that are able to travel at the maximum allowed speed. The digital map of the road network was developed from road segment data made available by the Ethiopian Road Authority. The sum of the two travel times is thus the total time it would require a farm household to take their dairy products to the central market of Addis Ababa using the existing road network. The computation of the measures of travel time are described in more detail in Appendix 1.

Transport times carefully measured using georeferenced data and digital maps of road networks are an improvement over self-reported travel times or (straight-line) geographical distances (see Chamberlin and Jayne (2013) for a discussion). However, road network-based travel times are not without their own measurement problems. The quality of georeferenced measurements depends on the quality of the digital map of the road network (i.e., are all roads digitalized with the correct road quality). The 2015 version of the road vector dataset published by the Ethiopian Road Authority used here is based on satellite imagery interpretation and has been verified on the ground by experts. However, actual travel times on roads is dependent on the nature of the terrain, while offroad travel times will also be dependent on land use. More remote households might face more challenging geographical barriers to transporting their produce to market. However, geographical constraints to movement are poorly accounted for in road network-based travel times. For example, road quality deterioration over time will not be captured in the road-network data used and speeds in hilly areas and on winding roads will be slower than the maximum allowed travel speed that we assume on each road segment.

\footnotetext{
${ }^{7}$ These results remain the same if we use the self-reported or the village level dairy price instead of the imputed prices, although we lose a substantial part of the sample.

${ }^{8}$ From January until February, the average conversion rate from ETB to USD was 0.03641 .

${ }^{9}$ Alternative measures are the self-reported travel time (minutes) to roads, market place, agricultural services, or place of sale of milk or other dairy products collected from household surveys.
} 
Moreover, from an analytical perspective, the geographical location of a dairy-producing household with respect to the central market may not be purely exogenous. If for example, the road network is denser and its quality is better in the area surrounding Addis Ababa, we might be picking up the endogenous location of households towards better roads near cities. Put differently, we expect roads to be better near Addis Ababa and, thus, households close to Addis Ababa will have a shorter travel time. However, these households also are more likely to be influenced by other effects due to their location close to the capital city, e.g., agglomeration effects. In this case, the travel time to the Addis Ababa market might capture more than just the effect of market access on various farm productivity decisions by dairy producers.

To address these concerns, we instrument travel time with the time it would take a farmer to walk (on foot, not using roads) from their farm to the central market of Addis Ababa. This measure has the advantage that it does not follow the existing road network, but follows a walking path that follows the actual terrain and other geographic conditions that minimizes the walking cost (in time) to Addis Ababa. To calculate this walking time, we follow the methodology of Vandercasteelen et al. (2018b) and Weiss et al. (2018), which is explained in more detail in Appendix 1. In essence, we construct a raster of pixels, each of which represent a small consistent square area of the land surface around Addis Ababa. Each pixel is assigned a travel time based on the actual use of the land area it represents, which is further adjusted for the effects of terrain, elevation, and the occurrence of natural barriers. A 'natural path' from the residence of each dairy producing household to the central market in Addis Ababa is then computed from this raster of pixels. This is the path from the household to Addis Ababa that will result in the shortest total walking time. The walking time (in hours) on this natural path for each household is used in our instrumental variable (IV) estimations below.

\subsection{Empirical set-up}

In the first part of the empirical analysis, we want to identify and measure the impact of urban remoteness on milk productivity. In the following sections, we start with graphically showing the correlation between travel time to Addis Ababa and different dairy indicators of interest. This is done by showing local polynomial smoothing estimates of transportation cost ( $\mathrm{x}$-axis) on dairy indicators ( $y$-axis). As these are reduced form parametric regressions, it does not require specifying a functional form ex-ante. As we will document below, most of these graphs nicely illustrate the spatial variation in different dairy indicators. However, these graphs only document spatial correlations between production, marketing, and input decisions in Ethiopian dairy production; but correlation is not causality, and remoteness might affect dairy productions in many different ways.

To empirically estimate the effect of urban remoteness on dairy production or productivity, we apply the following estimation methodology. First, we control for characteristics of the household and village that might affect dairy production and at the same time are likely to change with distance. These controls include the level of schooling, age, gender, ownership of a mobile phone by the household head; membership in a cooperative, dependency ratio, herd size, size of the household's farm, and the population of the local village. Second, to take into account that households living in the same village are likely to be similar in their characteristics of dairy production, we cluster standard errors at village level. We also bootstrap the standard errors to improve asymptotic inference and because we have a rather small number of clusters (42 villages). Finally, as explained in section 3.2, to address (some of the) concerns about the endogeneity of remoteness with respect to dairy production outcomes, we instrument the travel time from Addis Ababa with the least cost measure to travel from the farm to Addis Ababa on foot.

The equations that we estimate are the following: 


$$
\begin{gathered}
\mathrm{Y}_{i}=\alpha_{\mathrm{y}}+\beta_{\mathrm{y}} * \mathrm{~T}_{i}+\mathrm{X}_{i} * \Pi_{X}+\varepsilon_{\mathrm{i}, \mathrm{y}} \\
\mathrm{T}_{i}=\alpha_{T}+\beta_{\mathrm{T}} * \mathrm{~N}_{i}+\mathrm{X}_{i} * \Pi_{X}+\eta_{\mathrm{i}, \mathrm{T}}
\end{gathered}
$$

Where:

- $\quad Y_{i}$ is milk productivity (liter per day or liter per day per cow)

- $\quad \mathrm{T}_{i}$ is the road network-based travel time to Addis Ababa (hours) with coefficient $\beta_{\mathrm{y}}$

- $\mathrm{N}_{i}$ is the natural path cost travel time (hours) to Addis Ababa with coefficient $\beta_{\mathrm{T}}$

$-\quad X_{i}$ is a set of controls with vector of coefficients $\Pi_{X}$

- $\varepsilon_{\mathrm{i}, \mathrm{y}}$ and $\eta_{\mathrm{i}, \mathrm{T}}$ are the idiosyncratic error terms with respect to $\mathrm{Y}_{i}$ and $\mathrm{T}_{i}$

The first stage results of the estimation of Equation (2) are reported in Table 3.1. The natural path measure, which is the time it takes to walk from the farm to the central market in Addis Ababa, is strongly and significantly correlated with the travel time to Addis Ababa using road infrastructure. Each additional hour of walking time increases - all else being equal - the travel time to Addis Ababa by 5 minutes. The bottom of Table 3.1 reports the first-stage tests for weak instruments. The different R-squared measures (normal, partial, and adjusted) indicate a strong correlation (over 0.63 ) between the natural path walking time and transportation time to Addis Ababa. The F-statistic is significantly different from zero, large in magnitude, and is therefore well above the critical values. This suggests that the natural path variable is sufficiently strongly correlated to the endogenous travel time and makes it a valid instrument for the instrumental variable (IV) estimation.

\section{Table 3.1: First stage regression to instrument travel time to Addis Ababa with a}

\begin{tabular}{|c|c|c|}
\hline \multirow[b]{2}{*}{ First stage regression } & \multicolumn{2}{|c|}{$\begin{array}{l}\text { Travel time to Addis Ababa } \\
\text { (hours) }\end{array}$} \\
\hline & Coefficient & Standard Error \\
\hline Natural path (travel time by foot, hours) & $0.071^{\star \star \star}$ & $(0.002)$ \\
\hline Household head had any schooling (\%) & 0.021 & $(0.062)$ \\
\hline Age of household head (years) & -0.0001 & $(0.002)$ \\
\hline Household head is male (\%) & -0.040 & $(0.100)$ \\
\hline Household head has mobile phone (\%) & $-0.270^{\star \star \star}$ & $(0.066)$ \\
\hline Household is member of dairy cooperative & $-0.360 * \star$ & $(0.150)$ \\
\hline Household dependency ratio (\%) & 0.052 & $(0.140)$ \\
\hline Population density (number of people/km²) & $-0.00004^{\star *}$ & $(0.00002)$ \\
\hline Cattle herd size (number of animals) & $0.016^{\star \star *}$ & $(0.005)$ \\
\hline Farm size (ha) & 0.013 & $(0.014)$ \\
\hline Constant & 0.036 & $(0.180)$ \\
\hline Observations & \multicolumn{2}{|c|}{870} \\
\hline R-squared & \multicolumn{2}{|c|}{0.683} \\
\hline Adjusted R-squared & \multicolumn{2}{|c|}{0.68} \\
\hline Shea's Partial R-squared & \multicolumn{2}{|c|}{0.64} \\
\hline Robust F(1,869) & \multicolumn{2}{|c|}{$1528^{\star \star \star}$} \\
\hline
\end{tabular}
measure of time to travel there on foot

Source: Authors.

Notes: Standard errors are bootstrapped and clustered at village level and reported in parentheses next to the coefficient: $\star \star \star ~ p<0.01, \star \star$ $p<0.05,{ }^{*} p<0.1$.

In the second step, we try to better understand the spatial heterogeneity in milk productivity by looking at how urban remoteness affects different dairy outcome indicators. To do so, we estimate 
the effect of travel time to Addis Ababa on (i) dairy production and marketing decisions (i.e., the von Thünen hypothesis); (ii) dairy output prices; (iii) input use (agricultural intensification); and (iv) access to modern value chains and the technologies available within them (i.e., access to buyers with proper cooling or storage technologies). To do so, we run regressions similar to Equation (1), but where we replace $Y_{i}$ with a set of variables that proxy one of the dairy indicators considered. This allows us to detect and measure the size of the direct effect of travel time on these indicators. However, input decisions in dairy production are likely to be taken simultaneously by the household members and, hence, these decisions tend to be correlated. To control for this, we combine the IV strategy with a Seemingly Unrelated Regression approach. ${ }^{10}$

In a final step, we want to empirically test which of the above mechanisms captures the effect of travel time on milk productivity. However, dairy production and marketing behavior are decisions taken by the households, depending on the access to markets that they face, and highly endogenous with respect to the level of milk productivity achieved by the household. Hence, it would be difficult to credibly interpret the direction of the effect, i.e., is it the marketing outlet that affects productivity levels or vice versa (reverse causality). Instead of using household's actual marketing outcomes, we add different village-level indicators that represent households' access to dairy output markets. We further assume that households have limited influence on the dairy output prices they face - they are price takers - and assume that input application affects dairy yields and not vice versa, i.e., a dairy production function. Hence, we have a set of three indicators - dairy prices, input uptake, and access to dairy value chains - that we will add first stepwise and later all together to Equation 1 to capture (one of) the mechanisms hypothesized. Equation 1 and 2 then become:

$$
\begin{aligned}
& \mathrm{Y}_{i}=\alpha_{\mathrm{y}}+\beta_{\mathrm{y}} * \mathrm{~T}_{i}+\mathrm{X}_{i} * \Pi_{Y, X}+\mathrm{P}_{i} * \Pi_{Y, P}+\mathrm{I}_{i} * \Pi_{Y, I}+\mathrm{W}_{i} * \Pi_{Y, W}+\varepsilon_{\mathrm{i}, \mathrm{y}} \\
& \mathrm{T}_{i}=\alpha_{T}+\beta_{\mathrm{T}} * \mathrm{~N}_{i}+\mathrm{X}_{i} * \Pi_{X}+\mathrm{P}_{i} * \Pi_{T, P}+\mathrm{I}_{i} * \Pi_{T, I}+\mathrm{W}_{i} * \Pi_{T, W}+\eta_{\mathrm{i}, \mathrm{T}}
\end{aligned}
$$

Where:

- $\mathrm{Y}_{i}, \mathrm{~N}_{i}, \mathrm{Z}_{i}, \mathrm{X}_{i}, \varepsilon_{\mathrm{i}, \mathrm{y}}$ and $\eta_{\mathrm{i}, \mathrm{T}}$ are defined the same as before

- $\quad P_{i}$ refers to prices for milk, butter, cheese (ETB per liter or $\mathrm{kg}$ )

- $\mathrm{I}_{i}$ refers to input application dummies (\%) or rates $(\mathrm{kg})$ of the household for the feeding practices, importance of crossbred, and the use of artificial insemination

- $\quad \mathrm{W}_{i}$ refers to household's access (\%) to dairy markets and services provided by buyers

\section{SPATIAL VARIATION IN MILK PRODUCTION AND PRODUCTIVITY}

We start the empirical analysis with documenting the central observation of the paper that there is strong spatial heterogeneity in dairy production and productivity. Total dairy output is captured by the total output of milk, yoghurt, butter, baadu, and cheese - all expressed in milk liter equivalents and thus refers to the production of raw milk. The first graph of Figure 4.1 plots how the quantity in liters of total dairy (raw milk) production, liquid milk production, and the production of processed dairy during the last month varies over travel time to Addis Ababa. Total dairy production in milk equivalent is over 400 liter per month for households closely located to Addis Ababa and decreases sharply to 100 liter per month for households located at 4 hours travel time. Afterwards, total dairy

${ }^{10}$ In Stata, this is implemented using the 'reg3' command for three-stage estimation for systems of simultaneous equations 
production decreases further, but at a lower rate, to 50 liter per month. ${ }^{11}$ The spatial heterogeneity in total dairy production is strongly reflected in the spatial heterogeneity in the production of liquid milk (the dotted line), while the production of processed dairy seems to have a non-linear pattern. We will explore these production patterns in more detail in the next section.

\section{Figure 4.1: Milk production and productivity, by travel time to Addis Ababa}
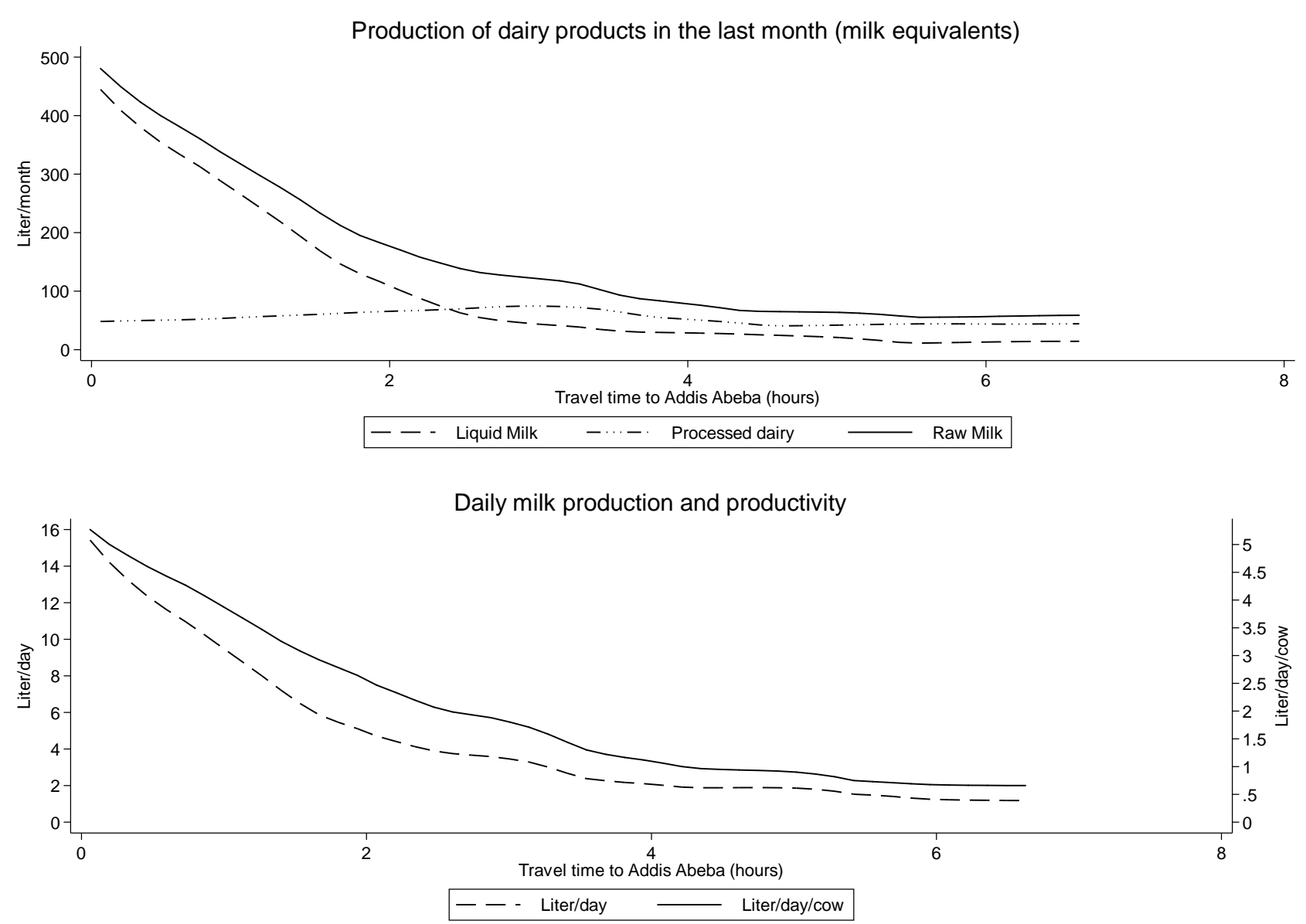

Source: Authors.

More importantly, there is also a strong heterogeneity in the quantity of raw milk that is produced per household and per cow. The second graph of Figure 4.1 shows how daily milk production defined as the quantity of raw milk (liter) produced by the farm per day - and productivity - defined as the milk quantity (liter) produced per cow per day - changes over travel time. Farmers that are closely located to Addis Ababa produce around 15 liter of milk per day or 5 liters of milk per cow per day. With increasing travel time from Addis Ababa, the productivity of dairy farmers decreases. At 4 hours travel time from Addis Ababa, dairy farmers obtain 2 liters of milk per day or 1 liter of milk per cow per day. This is a fivefold decrease in milk productivity.

In the simplest set up of the empirical model, we estimate the direct effect of travel time to Addis Ababa on the productivity of dairy farmers. ${ }^{12}$ In Table 4.1, production is captured by the quantity of raw milk in liter per day (column 2) and productivity of raw milk in liter per day per cow (column 3). Travel time to Addis Ababa using the existing road network, instrumented by the walking time to Addis Ababa, has a strong and statistically significant effect on dairy productivity. All else equal, an increase of the travel time by one hour decreases the daily production of raw milk by dairy farms by

${ }^{11}$ The value of total dairy production during the last month follows the production pattern closely, and decreases from 500 USD to 50 USD per month.

${ }^{12}$ Equation 1 assumes a linear effect of travel time on milk productivity. When adding the squared term of travel time to the equation, the level and quadratic effect of travel time on productivity is weakly or non-significant. We therefore retrain the assumption of a linear effect. 
2.6 liters, and the daily milk productivity by 0.77 liters per cow. Regarding the control variables, cooperative membership is important for the productivity per cow, as dairy cooperatives in Ethiopia primarily operate as facilitators of technology adoption (Chagwiza et al. 2016). Productivity is also determined by the size and composition of the cattle herd, which could be related to the liquidity constraints and the resource endowments of dairy producers in Ethiopia (Freeman et al. 1998). However, most of the control variables do not have a consistent impact on the two milk yield indicators.

Table 4.1: Yields and travel time to Addis Ababa

\begin{tabular}{lcc}
\hline Sample mean (for all households) & $\begin{array}{c}\text { Daily production } \\
\text { (liter/day) }\end{array}$ & $\begin{array}{c}\text { Productivity } \\
\text { (liter/day/cow) }\end{array}$ \\
\hline Mean for households with travel time $<30 \mathrm{~min}$ & 7.06 & 2.99 \\
\hline Explanatory variables: & 19.18 & 6.37 \\
\hline Travel time to Addis Ababa (hours) & & $-0.77^{\star \star \star}$ \\
\hline Household head had any schooling (\%) & $-2.64^{\star \star \star}$ & $(0.23)$ \\
\hline Age of household head (years) & $(1.01)$ & 0.46 \\
\hline Household head is male (\%) & $2.84^{\star \star}$ & $(0.29)$ \\
\hline Household head has mobile phone (\%) & $(1.21)$ & -0.01 \\
\hline Household is member of dairy cooperative & 0.01 & $(0.01)$ \\
\hline Household dependency ratio (\%) & $(0.03)$ & -0.11 \\
\hline Farm size (ha) & -1.35 & $(0.48)$ \\
\hline Population density (number of people/km²) & $(1.80)$ & $0.69^{\star}$ \\
\hline Cattle herd size (number of animals) & 0.68 & $(0.37)$ \\
\hline
\end{tabular}

Source: Authors.

Notes: Standard errors are bootstrapped, clustered at village level, and reported in parentheses below the coefficient: $\star \star \star ~ p<0.01$, ** $p<0.05,{ }^{*} p<0.1$.

\section{SPATIAL VARIATION IN DAIRY FARMERS' HOUSEHOLD ECONOMY}

\subsection{Agricultural production decisions}

We start by investigating the spatial location theory in agriculture and rural employment. Figure 5.1 shows the contribution of different livelihood activities to total household income, where the latter is defined as the sum of the value of production (quantity * price) for crop and dairy production and the income from non-agricultural activities. The red horizontal line represents the 50 percent line. It is immediately evident that dairy and crop production are the most important livelihood activities for dairy farmers, as combined, both account for nearly 90 percent of households' revenues. Given the 
purposive sampling of dairy producers in our survey, this does not come as a surprise. However, it is interesting to note that crop production remains important and becomes the most important source of income for more remote dairy producers. The relative contribution of dairy and crop production to total household income changes substantially over distance: close to Addis Ababa, dairy income accounts for almost 60 percent of household income, but that share declines to 30 percent for more remote farmers. Income from crop production accounts for more than 50 percent of household income for these remote farmers. Other agricultural income activities (e.g., rental of equipment or animals) or non-agricultural income (e.g., wage income) never account for more than 10 percent of household income.

Figure 5.1: Production decisions, by travel time to Addis Ababa
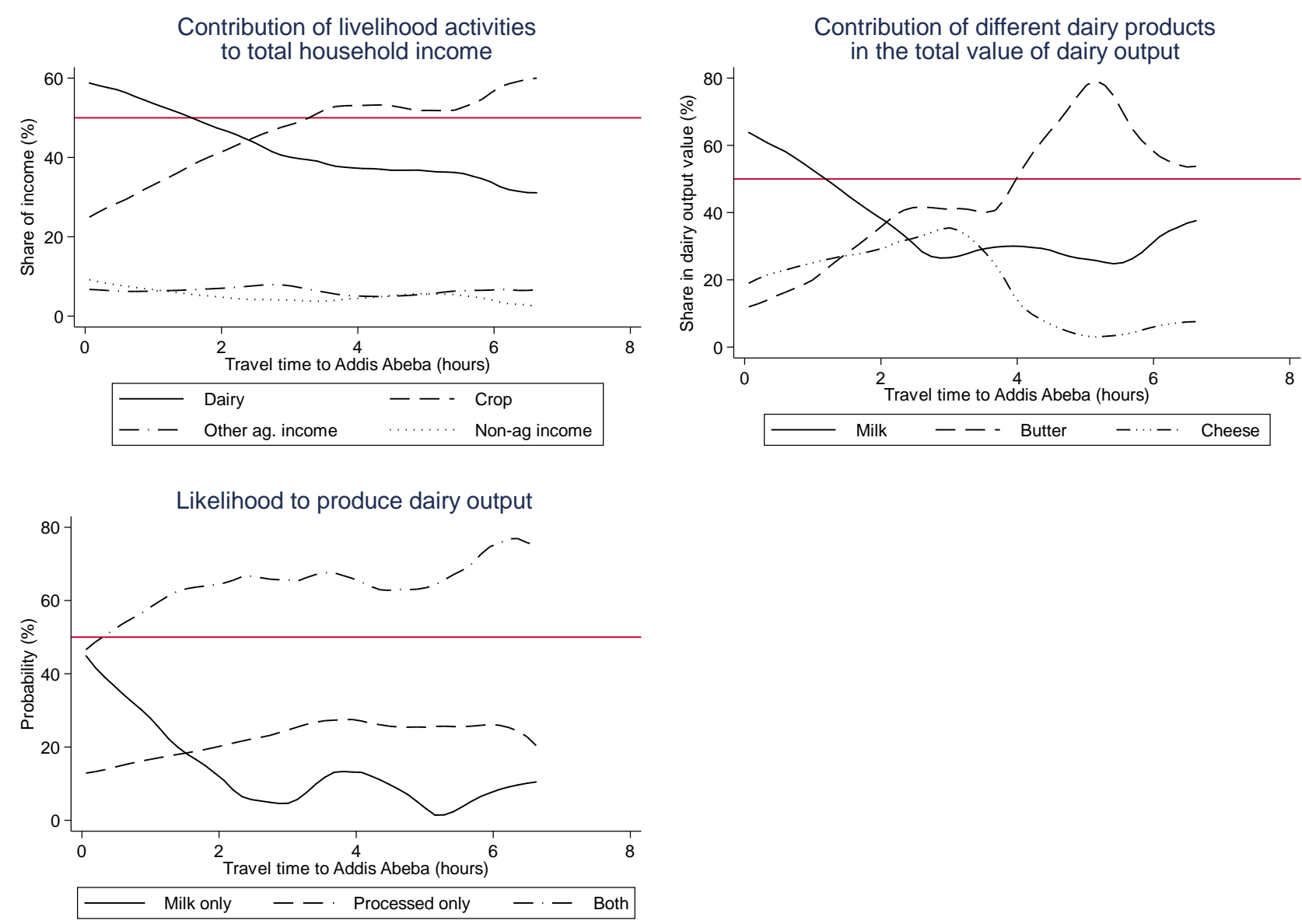

Source: Authors.

While the contribution of dairy production to household income declines with travel time, it remains highly important, as it still contributes to nearly one third of household's income. However, within the dairy sector, an important shift occurs in the type of dairy product that is produced, and how it contributes to the total value of dairy production. The production of liquid milk dominates the production of processed dairy products (butter and cheese) very close to Addis Ababa, but at increasing distance from the capital, the relative share of processed dairy (and especially butter) increases. This is illustrated in the graph at upper-right in Figure 5.1, which plots the share of different dairy products in the monetary value of household's raw milk production (i.e., total of all dairy products). For households living within an hour of travel time to Addis Ababa, liquid milk production accounts for more than 50 percent of dairy output value. For household more distant from Addis Ababa, the share of liquid milk in total dairy output value declines and stabilizes around 30 percent after 3 hours of travel time. The share of the value of dairy output accounted by butter production increases with travel time and becomes the dominant dairy product after 2 hours of travel time. The contribution of cheese increases with growing travel time from Addis Ababa but 
declines again after 3 hours of travel time. Hence, we observe a substitution of the type of dairy product (liquid milk vs. processed products) over travel time up to 3 hours. ${ }^{13}$ At greater distances from Addis Ababa, the contributions of both milk and processed dairy products to total dairy output decrease with travel time, but at a lower rate. ${ }^{14}$

The graph at lower-left in Figure 5.1 shows the likelihood that households produce dairy output, where we distinguish between households that only produce liquid milk; households that only produce processed dairy products, and households that produce both. We observe, first, that the majority of households produces both, and that the probability that a household does so increases with travel time. While the probability that a household produces liquid milk only is relatively high for those located close to Addis Ababa; it decreases with increasing travel time, although there are non-linearities detected. The probability that households specialize in the production of processed dairy products starts from a low base, and increases steadily for households located at a distance from Addis Ababa of 4 hours of travel time, after which it flattens off. This figure suggests that specialization in milk production only occurs for households close to Addis Ababa, while the majority of households produces both milk and processed dairy products and this proportion increases with distance.

\subsection{Marketing behavior}

Following the different dairy production outcomes over space, we observe different marketing decisions of dairy products over travel time to Addis Ababa. The upper-left graph in Figure 5.2 shows the likelihood that a household sells no dairy product of any kind, sells only liquid milk, sells only processed dairy products, or sells both type of dairy products. First, we see that a substantial share of farmers does not sell any dairy output. Close to Addis Ababa, 25 percent of the households does not sell dairy products, but this share increases with remoteness to nearly 50 percent for households with travel times over 4 hours. There is a substantial share of households that only sell liquid milk close to Addis Ababa, but that share drops thereafter first at a sharp rate and later at a lower rate. The share of households that only sells processed dairy output mirrors this pattern over time, and increases from 20 percent close to Addis Ababa to 50 percent at larger travel times to Addis Ababa. The spatial pattern of marketing of both types of dairy output, thus, strongly reflects the pattern of production specialization that was observed in Figure 5.1. Finally, the share of households that sells both liquid milk and processed dairy products is small, and becomes zero at larger travel times to Addis Ababa.

The upper-right graph in Figure 5.2 shows the absolute value (in USD) of the sales of liquid milk, butter, and cheese by the household in the last month. ${ }^{15}$ Note that the figure for processed dairy products is plotted on a different axis than the figure on the left (tenfold difference). The axis on the left shows that the value of liquid milk sales is very large at around 200 USD in the last month for dairy farmers living close to Addis Ababa, but this value declines sharply afterwards. At a travel time of 2 hours from Addis Ababa, the value of processed dairy sales becomes more important, while the value of liquid milk sales becomes small. Cheese is the most important processed dairy product sold, but cheese sales decline with growing distance from Addis Ababa. In contrast, the sales of

\footnotetext{
13 There seems to be a nonlinear pattern in the relationship between the production of processed dairy products and travel time. The contribution of butter to the household income increase with travel distance, but spikes at 4 hours of travel time, after which its contribution again declines. The contribution of cheese to dairy production value spikes at a distance closer to Addis Ababa (at 3 hours of travel time), and quickly drops afterwards.

14 The contribution of two other dairy products, baadu and yoghurt, to dairy total value are not reported. The production of baadu increases with travel distance and becomes the most produced dairy product for households with larger travel times (but quantity wise, it is still very small). The production of yoghurt does not show much spatial variation.

${ }^{15}$ Both quantities of liquid milk and (total) processed dairy products sold by households follow a similar pattern over travel distance as the production quantities produced in Figure 5.1 and hence the results are not shown. The results for yoghurt and baadu are not reported as these dairy products are rarely sold
} 
butter show a nonlinear pattern, which spikes at 3 hours of travel time, declines afterwards, but increases again after 4 hours of travel time.

\section{Figure 5.2: Marketing decisions and sales values, by travel time to Addis Ababa}
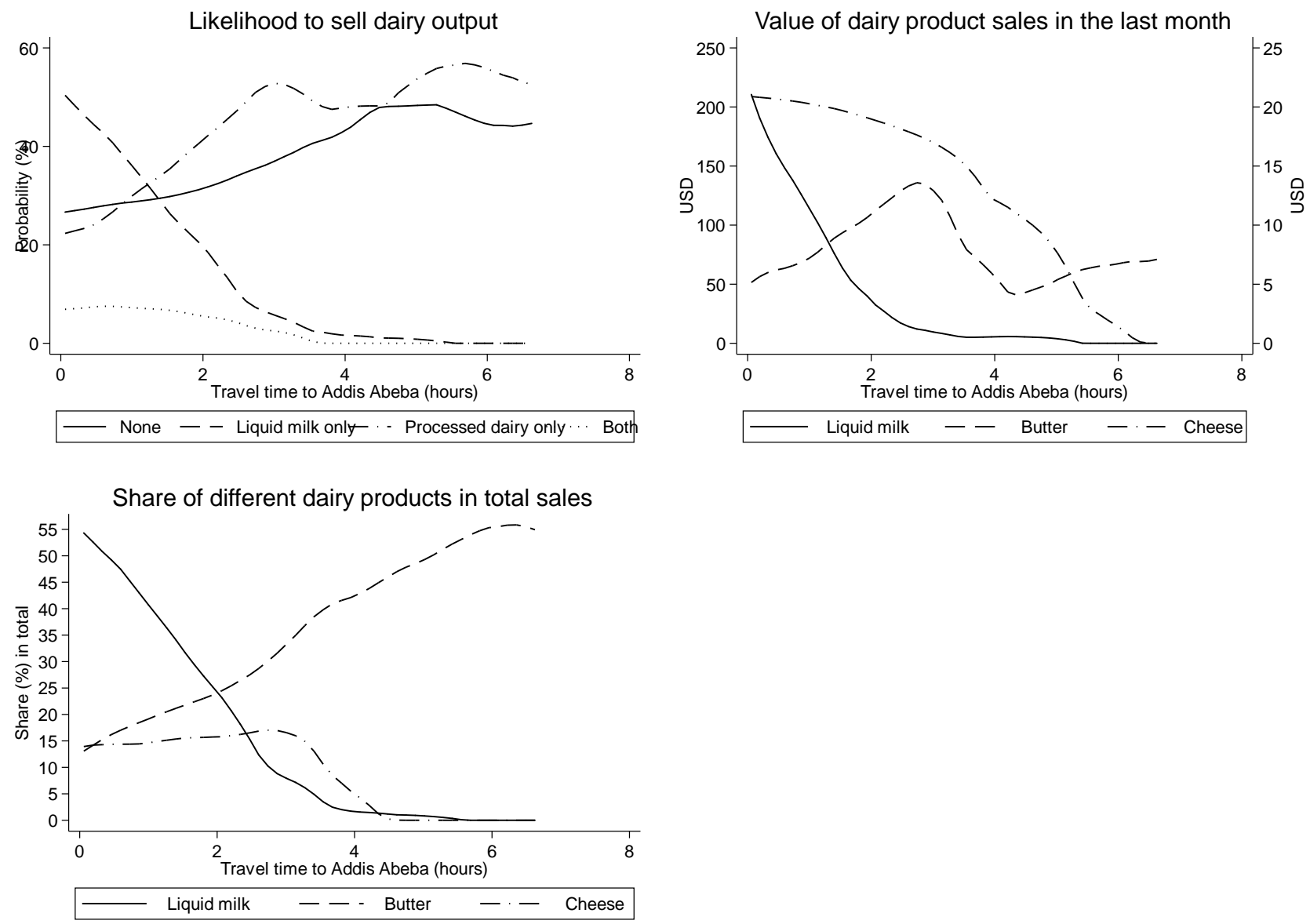

Source: Authors.

The graph at lower-left in Figure 5.2 shows that liquid milk sales dominate for households up to 2 hours of travel time from Addis Ababa. Afterwards, butter becomes the most important dairy product sold and becomes the only dairy product sold by farmers located more than 5 hours away.

Figure 5.3 shows the different destinations for the liquid milk and processed dairy products sold by farmers and the types of buyers. ${ }^{16}$ Here, we assume that households that did not sell any of the dairy output have zero value (hence, not missing values). ${ }^{17}$ The majority of liquid milk sold is shipped to Addis Ababa and ends up in the market there. Very little liquid milk ends up in regional or woreda markets. The main buyers of liquid milk for farmers close to Addis Ababa are consumers, traders, and, to a smaller extent, processing companies. In contrast, processed dairy products are more often sold in woreda or regional markets and to traders. The share of households for which the processed dairy products they sold ends in Addis Ababa shows an interesting pattern. While it is relatively small for farmers located close to Addis Ababa, its share increases for households located between 2 and 3 hours of travel time from the city. Afterwards, the share of farmers whom marketed

${ }^{16}$ The questions inquired about the type of buyer and where the product sold was most likely to be finally consumed:

(1) To whom did you sell (most important buyer for this product type)? Possible answers: Consumer - neighbor, Other consumer, Agent of processing company, Processing company directly, Agent of cooperative, Cooperative directly, Independent trader/collector, Retail shop, Yoghurt shop, School-institution, Cafés/restaurants/hotels, and Other.

(2) Where was product sold to final consumer for this buyer type (most important buyer)? Possible answers: Local - no market, Kebele market, Woreda market, Regional market, and Addis Ababa.

${ }^{17}$ Note that we pool together the households with travel time over 5.5 hours because there are only a few households in the half hour categories after 6 hours of travel time. 
processed dairy products arrives in the Addis Ababa market becomes small but not zero. Traders are the most important buyers of processed dairy products, but the share of farmers that sell such products to traders fluctuates over travel time to Addis Ababa.

Figure 5.3: Milk and processed dairy sales characteristics, by travel time to Addis Ababa
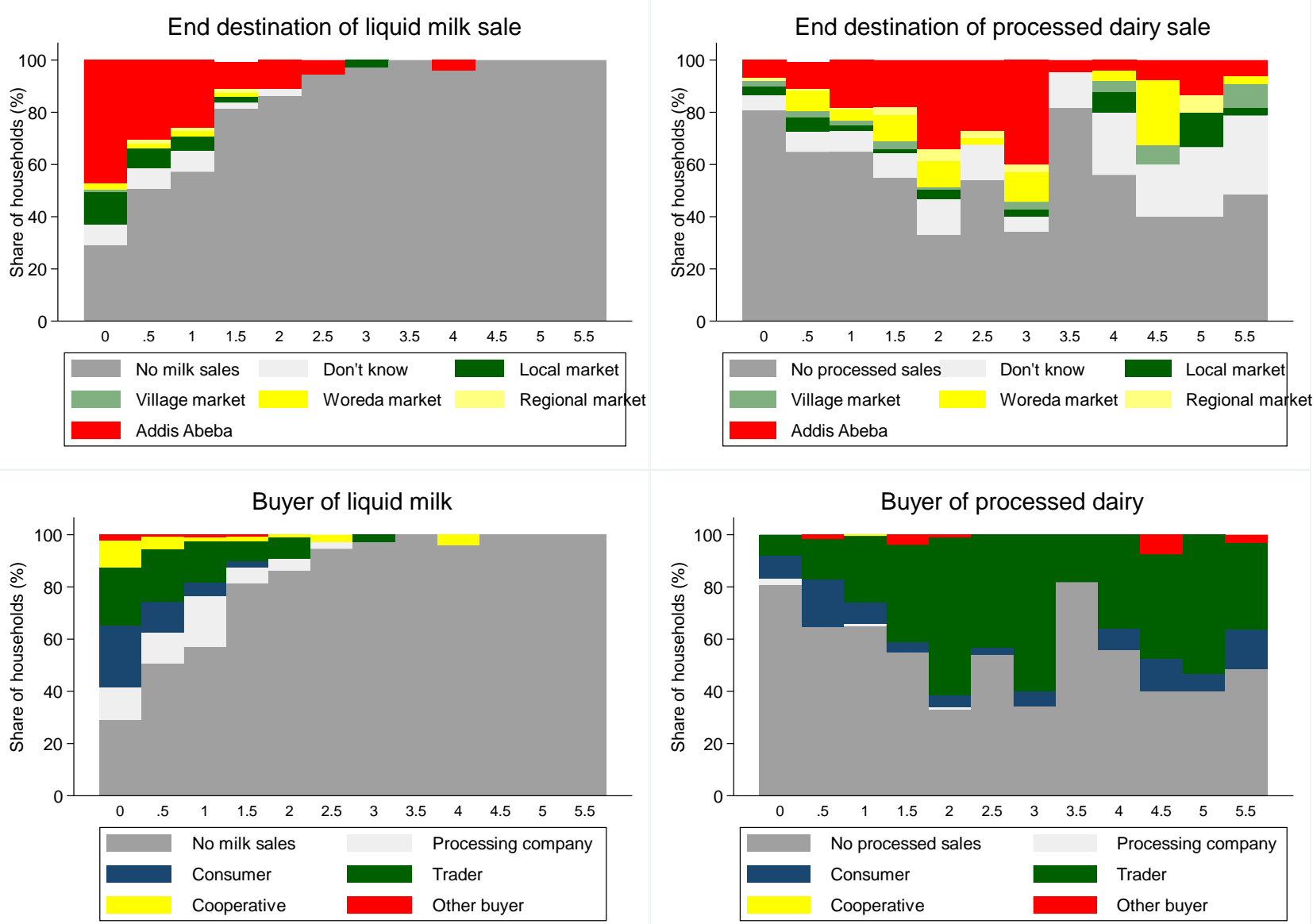

Source: Authors

Note: $x$-axis refers to time intervals of 30 minutes, where ' 0 ' refers to $<30 \mathrm{~min}$, ' 0.5 ' to $30 \mathrm{~min}-1 \mathrm{hour}$, ' 1 ' to $1 \mathrm{~h}-1 \mathrm{~h} 30 \mathrm{~min}$, etc.

\subsection{Output and input prices}

Figure 5.4 plots the (imputed) prices of different dairy products based on the transaction data for the last month before the interview. Note the different units between milk (price per liter) and processed products (price per $\mathrm{kg}$ ), and the difference in magnitude, which represents the number of milk equivalents needed to produce a $\mathrm{kg}$ of processed dairy products. The graph at upper-left shows that milk prices (ETB per liter) drop with travel time, and stabilize after 2 hours of travel time. After 4 hours of travel time, we do not observe (individual or community level) prices anymore as no one is selling raw milk in remote places (see Figure 5.2), and the effect of travel time on imputed prices becomes flat. The price of butter and cheese (ETB per $\mathrm{kg}$ ) follows a similar pattern over travel time in the graph at upper-right, although the variation is less dramatic for butter and less precisely estimated for cheese. 
Figure 5.4: Dairy output and input prices, by travel time to Addis Ababa
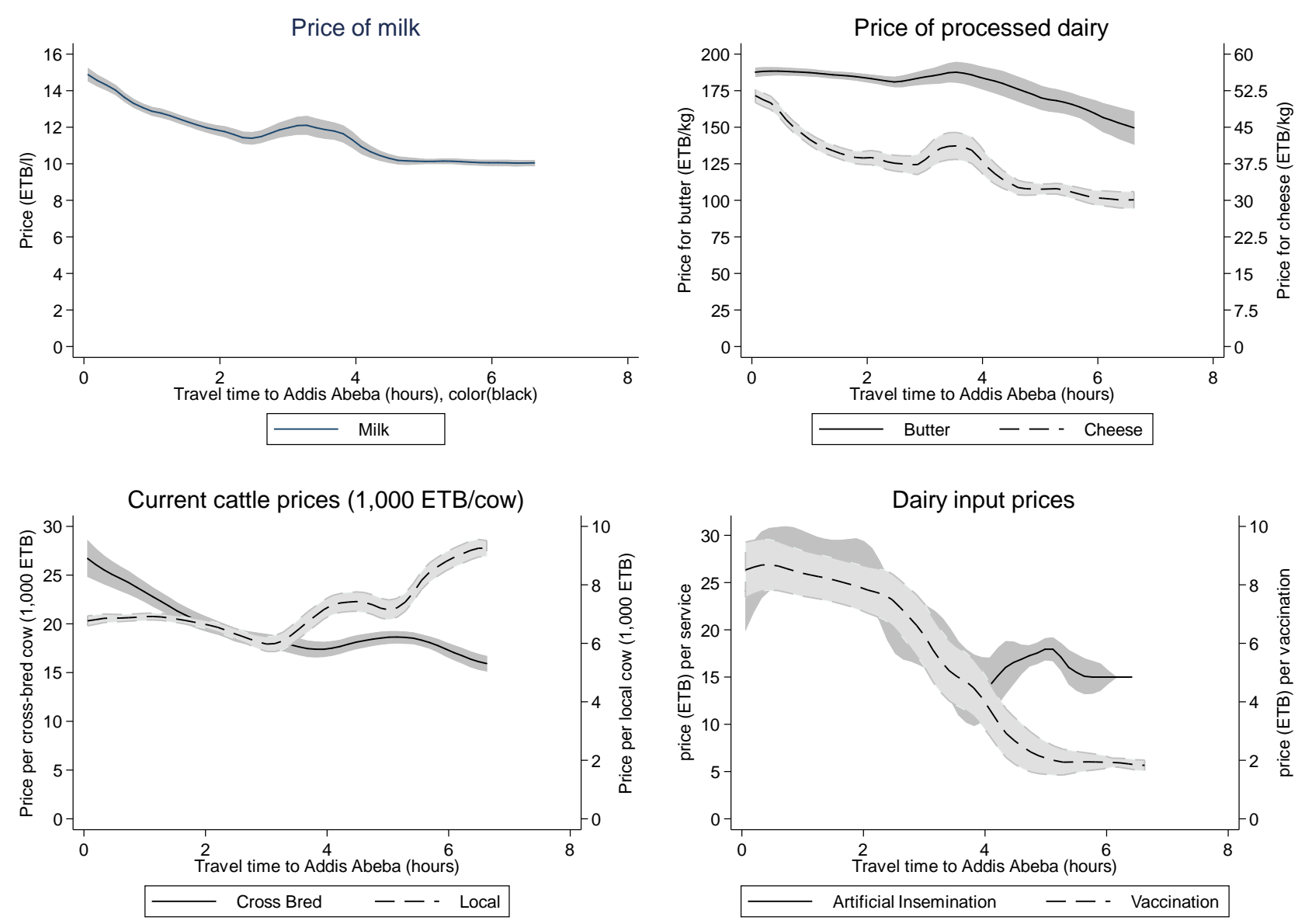

Source: Authors

The lower graphs of Figure 5.4 show the pattern of input prices over travel distance to Addis Ababa. This data mainly comes from the village questionnaire. The graph at lower-left shows the current, i.e., at the time of interview, prices of crossbreed and local cows. ${ }^{18}$ The price of crossbreed cows drops from 27,500 ETB per cow (i.e., about 1,000 USD per cow) to 15,000 ETB (or 550 USD) per cow after a travel time larger than 3 hours. Interestingly, the price of local cows shows the reverse pattern, but note the difference in price levels (the second $y$-axis). The price for local cows first stabilizes at 7,000 ETB (or 255 USD) per cow, but after 3 hours of travel time increases, to become over 9,000 ETB (or 328 USD) per cow in very remote villages. This could be related to the lower availability of cows for sale in more remote areas, thus signaling missing markets for cattle.

The graph at lower-right in Figure 5.4 shows the effect of travel distance on the per unit price of artificial insemination and vaccination against foot and mouth disease. The per unit price that farmers have to pay for artificial insemination decreases over travel time from 30 ETB to 15 ETB for more remote villages. The price farmers pay for vaccination is stable around 8 ETB per service for villages closely located to Addis Ababa, but drops to 2 ETB for farmers located in villages at 4 hours of travel time from Addis Ababa. The downward sloping pattern seemingly reflects lower demand for these services in more remote areas, even though these services seem to be available even in remote villages (see Figure 5.6).

\footnotetext{
18 The price of local cattle comes from the village questionnaire as but has a few missing observations ( $\mathrm{n}=819$ ). The price of crossbred cows is often missing in both the household and village data, and hence was imputed based on a regression of these prices on cow ownership (total number and value) and household characteristics. The non-imputed prices show similar spatial dynamics, but have fewer observations.
} 


\subsection{Inputs into dairy production}

The most important input into dairy production is the number of cattle and the type of cows owned. The graph at upper-left in Figure 5.5 shows how the total number of cattle owned by a household changes over travel distance. Up to a travel time of 4 hours, the total number of cows owned is more or less constant, but it afterwards makes a jump around 5 hours of travel time. The composition of the cattle stock also changes over travel time. While households within an hour travel time to Addis Ababa have more crossbred cows than local cows, the number of crossbred cows owned by the household decreases over travel time and, at the same time, the number of local cows increases. Crossbred cows are more productive and, hence, worth more than local types of cattle. The graph at upper-right in Figure 5.5 shows the evolution of the value of cattle stock over travel time. The total value of the household's cattle stock drops quickly with travel time up to four hours, after which the effect flattens out. This drop in total cattle value is mainly caused by the drop in the number of crossbred cows with increasing travel time.

Figure 5.5: Cow herd size and composition, by travel time to Addis Ababa
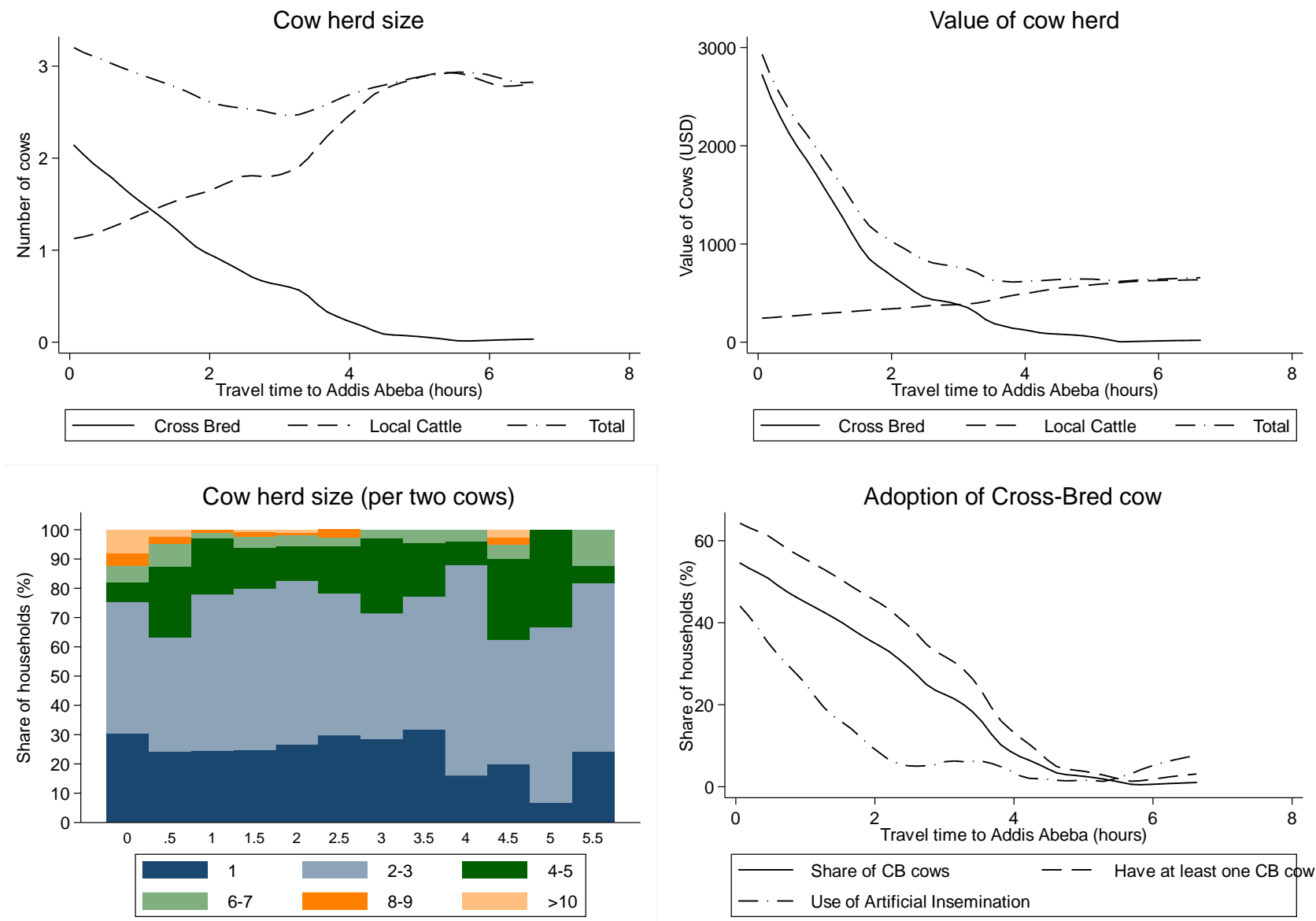

Source: Authors.

The cow herd size in the commercial milk zone of Ethiopia is small, as the median number of cows owned by households in our sample is two. Moreover, 25 percent of households own only one cow, and 50 percent of the households owns two or three cows. The graph at lower-left in Figure 5.5 shows how herd size changes with travel time by looking at the share of households that own less than two, two to three, four to five, etc. cows per household. The share of households that have only one cow does not vary much over travel time to Addis Ababa, except for the most distant households. Similarly, the share of households with two or three cows does not show much spatial heterogeneity. Larger herd sizes are mostly found for households located close to Addis Ababa. 
As improved genetic material is an important determinant of cattle value and productivity, the graph at lower-right in Figure 5.5 shows the share of crossbred cows in the total herd size and the probability that households have at least one crossbred cow. For households that are closer to Addis Ababa, half of their cattle stock consists of crossbred cows. Two out of three of these wellconnected households have at least one crossbred cow. Both the share of crossbred cows and the probability of having one decreases over travel time, becoming nearly zero after 5 hours of travel time. Comparing Figures 4.1, 5.2, and 5.5 illustrates that the likelihood that a household has at least one crossbred cow follows a similar pattern over travel time to Addis Ababa as the likelihood that farmers produce and sell liquid milk. This suggests that the adoption of cows with improved genetic material is strongly dependent on the type of dairy product produced and marketed.

The acquisition of crossbred cows might require the use of artificial insemination. The graph at lower-right in Figure 5.5 shows the likelihood that the household used artificial insemination for breeding of their cows. The share is above 40 percent for households in well-connected areas, but decreases with travel time and flattens out after 2 hours, although in a non-linear pattern.

\section{Figure 5.6: Inputs into dairy production, by travel time to Addis Ababa}
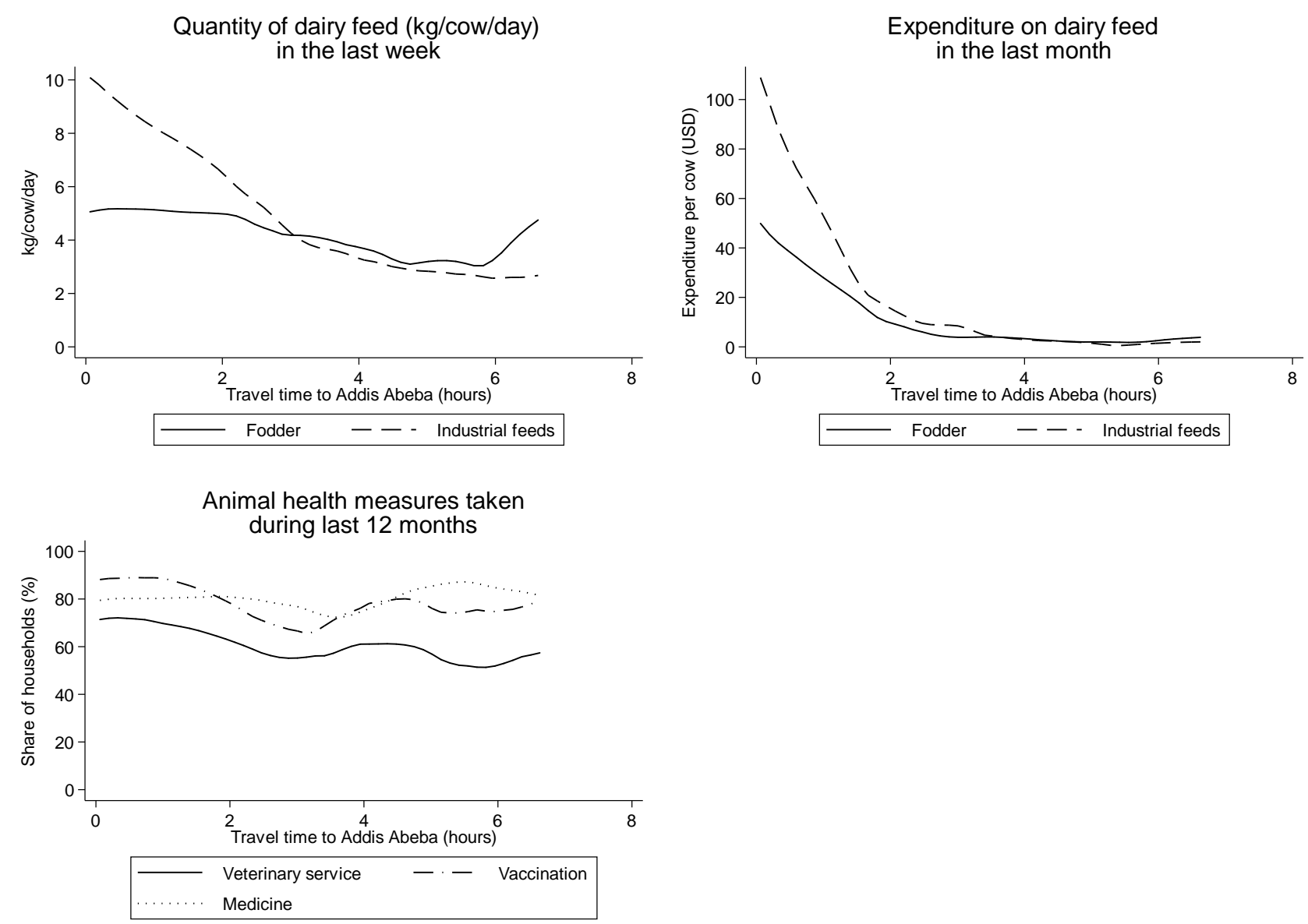

Source: Authors.

Other important determinants of dairy production are the type and quality of feeding and the maintenance of the cows. Duncan et al. (2013) and Minten et al. (2018) document a declining reliance of dairy households on grazing land for livestock feeding over time, potentially related with reduced access of private and communal grazing lands. Similarly, the share of households that rely only on grazing or stall feeding declines and increases over distance, respectively. There is also a seasonal effect, as less households are exclusively dependent on grazing during the dry season compared to the rainy season. Hence, there seems to be a shift over time and proximity towards stall-feeding. The feed used can be produced either by the household itself from fodder or crop 
residues or can be bought as an industrial byproduct or concentrated feeds. It has been shown that industrial feed increases milk production, and especially so for improved crossbreeds (Ayalew et al. 2015).

The graph at upper-left in Figure 5.6 shows the quantity of dairy feed used during the last week before the interview in $\mathrm{kg}$ per cow per day. We distinguish between fodder, including grain or crop residues, and industrial products, such as oil cake, bran, molasses, processed byproducts, or commercial concentrate mixes. Households that are located close to Addis Ababa mainly use industrial feeds for stall-feeding. However, the quantity of industrial feed (per cow per day) declines strongly with increasing travel time. After 3 hours of travel time, the use of fodder stall-feeding becomes equally important in quantity terms. The graph at upper-right in Figure 5.6 presents the expenditure of households during the last month, if any, on the purchase of fodder or industrial products. Because not all households purchased fodder, as it can come from their own crop production, there is a strong spatial variation in household total expenditure on both fodder and industrial products.

The graph at lower-left in Figure 5.6 shows the likelihood over travel time to Addis Ababa that households take measures related to animal health, including using veterinary services, vaccinations, or medicines. Overall, the usage shares are high, and there seems to be no clear spatial pattern in their application, potentially linked with the good provision of public veterinary health services in rural areas of Ethiopia (Ahmed et al. 2004; Minten et al. 2018).

\subsection{Access to the value chain, commercial buyers and services offered}

An important determinant of milk productivity is the access of dairy producers to buyers of liquid milk and the services offered by these buyers to farmers. Figure 5.7 explores the access of dairy farmers to buyers of liquid milk and processed dairy products at the village level. ${ }^{19}$ The solid line in the graph at upper-left shows that villages more remotely located from Addis Ababa have fewer liquid milk buyers present in the village. For villages close to Addis Ababa, there are - on average - two buyers available, but villages located further away have no access to a milk buyer. In contrast, the number of markets in which processed dairy products are sold within the village (dashed line) increases with travel time, from about one market for villages close to Addis Ababa, to almost three markets for more remotely located villages.

However, the graph at upper-right in Figure 5.7 shows that the number of traders in the market for processed dairy products in the village decreases significantly over travel distance from Addis Ababa. Thus, more remotely located villages have more markets in which dairy products are sold, but the number of traders within these markets is smaller. This could suggest that the type of buyer of processed dairy changes over travel time, i.e., from traders that buy up processed dairy to individuals and consumers in local markets. The graph also shows the number of independent milk collectors and the number of milk processing companies that operate within the villages. Close to Addis Ababa, villages tend to have access to several independent milk collectors, but this quickly drops to zero after three hours of travel time from Addis Ababa. The number of processing companies slightly increases with travel time first, but decreases thereafter to zero.

\footnotetext{
19 The data comes from the village questionnaire and is hence only available at village and not household level. The respondents of the village questionnaire were asked to list all different (processed) dairy markets and buyers of liquid milk of more than 50 liters and for consumption outside the village. This allows us to calculate the number of markets and milk buyers in the village, and if we look at information at market/buyer level, we take the maximum value (if there are multiple markets).
} 
Figure 5.7: Access to dairy buyers and services offered, by travel time to Addis Ababa
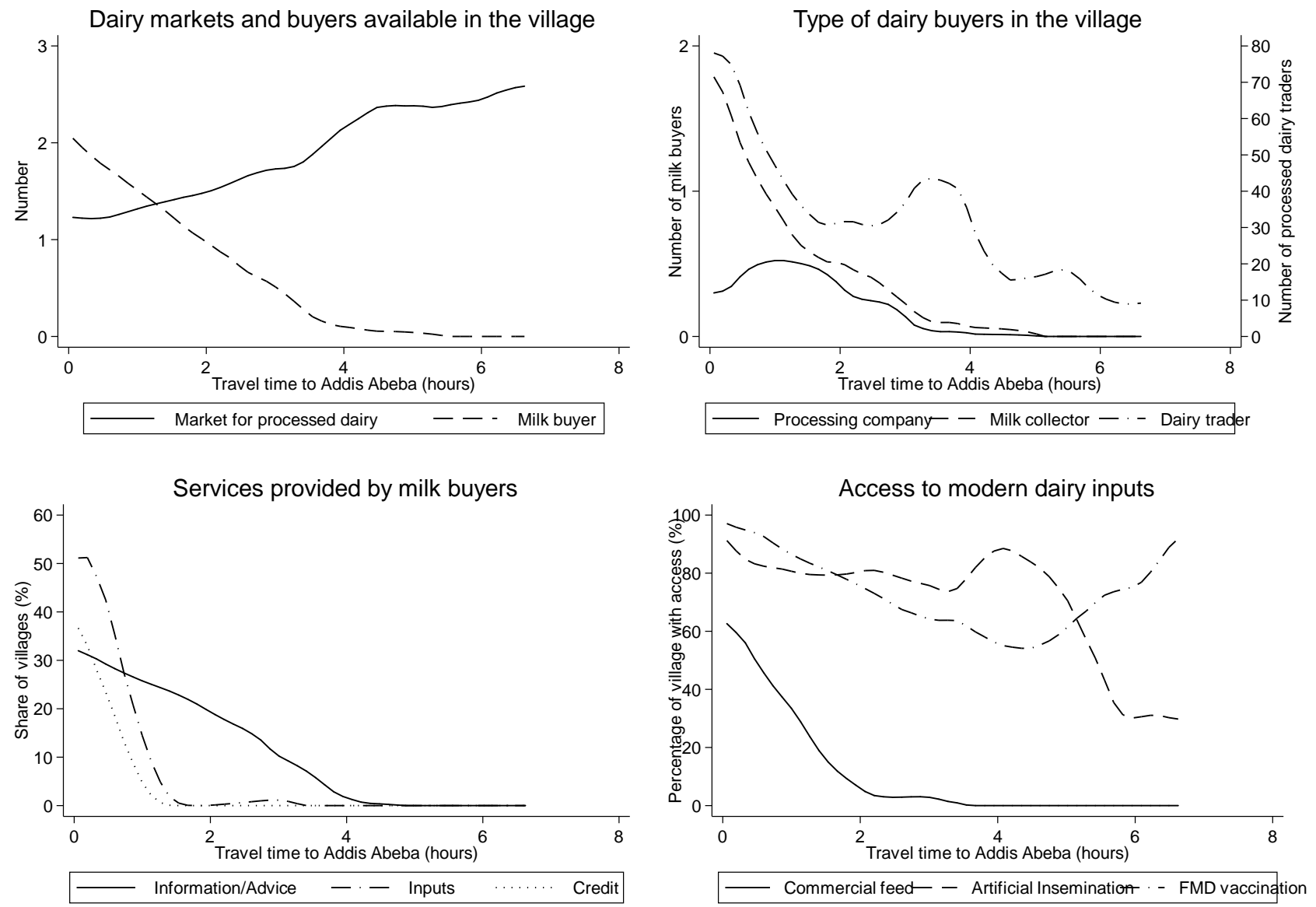

Source: Authors.

The graph at lower-left in Figure 5.7 shows the services that are provided by the buyers of liquid milk to dairy producers. While villages closely located to Addis Ababa have access to services provided by buyers (e.g., 50 percent of the villages responded that milk buyer(s) in the village distribute inputs to producers), this access to services and technologies quickly drops for villages located further away, in parallel with the drop in the number of buyers. This drop is most pronounced for access to credit and inputs: after one hour of travel time from Addis Ababa, almost none of the villages indicate that buyers provide these services to farmers.

The graph at lower-right in Figure 5.7 shows the availability of modern dairy inputs at village level through any source. Half of the villages located close to Addis Ababa indicated that they have access to commercial feed, but this input becomes nearly unavailable from 2 hours of travel time from Addis Ababa. Artificial insemination and foot and mouth disease vaccination seem widely available in rural Ethiopia. While access is high for well-connected villages, it remains available for half of the more remote villages. The exception to this pattern is for artificial insemination, which drops to 30 percent at 6 hours of travel time. The reasonably good access to these services reflects the effort of public Ethiopian agricultural extension agents to make basic veterinary and artificial insemination services available to more remote farmers (Minten et al. 2018; Kebebe 2019).

\section{MECHANISMS: SPATIAL VARIATION IN PRICES AND MARKET ACCESS}

The main interest of this paper is to empirically estimate the effect of travel time on dairy production and productivity and to unravel through which mechanism this urban proximity effect manifests 
itself. In this section, we first measure how travel time affects the different indicators discussed in section 5 . Then, we try to identify which of the mechanisms discussed is capturing the effect of travel time on dairy productivity.

\subsection{Direct effect of travel time on prices and market access}

In Table 6.1 we estimate Equation (1), but with different dairy outcome indicators. The different panels report the effect of travel time on dairy output prices (panel 1), input application (panel 2), and access to value chain buyers and services (panel 3 ). In this section, we only focus on the impact (regression coefficient, standard error, and $\mathrm{R}^{2}$ ) of travel time on the different outcome indicators, holding all else equal. The detailed regression outcomes of these estimations can be found in Appendix 2, which also includes regression outcomes of how input expenditure, household general production behavior, and dairy marketing behavior are affected by travel time. As indicated in section 3.3, all regressions are estimated using 2SLS.

Table 6.1: Dairy prices, input application, value chain access, and travel time to Addis Ababa

\begin{tabular}{|c|c|c|c|c|c|}
\hline \multirow[b]{2}{*}{ Dairy output prices } & \multicolumn{2}{|c|}{ Sample mean } & \multicolumn{3}{|c|}{$\begin{array}{c}\text { Regression of indicator in } \\
\text { Equation (1) }\end{array}$} \\
\hline & obs. & mean & coeff. & s.e. & $\mathbf{R}^{2}$ \\
\hline Milk (ETB per liter) & 403 & 13 & $-2.27^{\star \star \star}$ & $(0.79)$ & 0.311 \\
\hline Butter (ETB per kg) & 870 & 184 & $-4.44^{*}$ & $(2.52)$ & 0.048 \\
\hline Cheese (ETB per kg) & 520 & 43 & $-17.30^{\star \star}$ & $(7.66)$ & 0.046 \\
\hline \multicolumn{6}{|l|}{ Input application } \\
\hline Crossbred (\% of cattle) & 870 & 32 & $-9.63^{\star \star \star}$ & $(1.78)$ & 0.226 \\
\hline Crossbred (\% owning >0) & 870 & 49 & 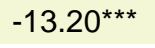 & $(2.06)$ & 0.213 \\
\hline Cows in milk production (number) & 870 & 1.7 & $-0.12^{\star \star}$ & $(0.05)$ & 0.477 \\
\hline Artificial insemination (\%) & 870 & 17 & $-5.58^{\star \star \star}$ & $(1.65)$ & 0.157 \\
\hline Veterinary service (\% in 12 months) & 870 & 64 & $-3.68^{\star \star}$ & $(1.85)$ & 0.043 \\
\hline Vaccination (\%) & 870 & 81 & $-3.37^{\star \star}$ & $(1.51)$ & 0.055 \\
\hline Medicine (\% in 12 months) & 870 & 80 & 0.17 & $(1.47)$ & 0.018 \\
\hline Purchase of fodder (kg) & 870 & 4.7 & -0.32 & $(0.24)$ & 0.040 \\
\hline Purchase of industrial feed (kg) & 870 & 6.8 & $-1.41^{\star \star \star}$ & $(0.40)$ & 0.100 \\
\hline \multicolumn{6}{|l|}{ Access to value chain buyers and services } \\
\hline Dairy markets in the village (number) & 839 & 1.6 & $0.31^{\star \star \star}$ & $(0.03)$ & 0.187 \\
\hline Liquid milk processing company buying in village (number) & 839 & 0.3 & $-0.02^{*}$ & $(0.01)$ & 0.047 \\
\hline Liquid milk collector buying in village (number) & 839 & 0.6 & $-0.27^{\star \star \star}$ & $(0.04)$ & 0.149 \\
\hline Traders active at dairy markets (number) & 839 & 40 & $-9.90^{\star \star *}$ & $(1.46)$ & 0.153 \\
\hline Buyer provides training \& advice (\%) & 839 & 19 & $-4.01^{\star \star \star}$ & $(0.95)$ & 0.096 \\
\hline Buyer distributes inputs and credit (\%) & 839 & 9.5 & $-9.25^{\star \star \star}$ & $(1.03)$ & 0.154 \\
\hline Buyer provides services (\%) & 870 & 14 & $-3.59 * \star \star$ & $(0.73)$ & 0.092 \\
\hline
\end{tabular}

Note: Sample mean refers to the sample average and 'obs.' to the number of observations. The last three columns report the most important effects of Equation (1): 'coeff.' represents the regression coefficient of travel time on the dairy indicator from the IV estimation, the number between brackets is the bootstrapped and kebele clustered standard error. ${ }^{* *} p<0.01,{ }^{\star *} p<0.05,{ }^{*} p<0.1$.

Panel 1 of Table 6.1 shows that travel time to Addis Ababa has a negative and significant effect on the self-reported (not imputed) prices farmers receive for milk, butter, and cheese. The effects are the strongest and most significant for the price of milk and cheese. An additional hour of travel time to Addis Ababa reduces the price of milk by 2.3 ETB per liter and the price of cheese by 17 ETB per kilogram. As the average amount of milk sold is 543 liter per month for selling households, this would result in a drop of 1,250 ETB or 45 USD in the value of sales if the same amount would be sold by farmers who are located one hour of travel time further away. For cheese, the drop in the value of sales of the average amount $(13 \mathrm{~kg})$ of cheese would be $221 \mathrm{ETB}$ or 8 USD. 
Travel time has a significant negative effect on input applications and expenditures into dairy production (panel 2 and Appendix 2). Increasing travel time significantly reduces the share of households using crossbreed cows, artificial insemination, veterinary services, vaccination, the number of cows in milk production, and the application of industrial feed. It, however, does not affect the likelihood that households use medicine or the amount of fodder. The effects of travel time on farmers' expenditures on these inputs, shown in Appendix 2, show a similar pattern as the application dummies. However, the effect of travel time on the expenditure of fodder is significant, while that of veterinary services is not, possibly reflecting the mostly public nature of these services.

The third panel of Table 6.1 reports the effect of travel time on different community-level indicators of household's access to commercial buyers in the dairy value chain, and the services that these buyers provide to clients. These regression results confirm the correlations observed in Figure 5.7. Travel time has a significant positive effect on the number of markets within the village where dairy (processed) products are sold, and a significant negative effect on the number of traders active within these dairy markets. Travel time also has a negative effect on the number of processing companies that buy liquid milk in the village, and a strongly negative effect on the number of independent collectors that buy up milk in the village. Finally, Table 6.1 also shows that travel time has a significant and strong effect on the services provided by buyers.

We briefly discuss some interesting effects of travel time on other dairy indicators reported in Appendix 2. Travel time has a significant effect on the production behavior of milk producing households in our sample. With increasing travel time from Addis Ababa, the contribution of dairy in household income decreases, while the contribution of crop production increases. There is not much effect of travel distance on other agricultural income or non-agricultural income sources. Travel time does significantly affect the decision of a household to specialize in the production of milk only, as for each additional hour of travel time, the share of households that produce liquid milk as end product only is reduced by 5 percent, although this result is statistically significant at only the 10 percent level. Travel time has a more pronounced effect on dairy marketing behavior: each additional hour of travel time increases the likelihood that a household did not sell any type of dairy product by almost 10 percent, while the likelihood that a household sells liquid milk only is reduced by 8 percent. As such, the total value of milk sales and its contribution to dairy income decreases significantly over travel time. The relative importance of butter increases with increasing travel time, while that of cheese decreases.

\subsection{Disentangling the effect of travel time}

To better understand through which mechanism(s) travel time to Addis Ababa introduces considerable spatial heterogeneity in the milk productivity of dairy producers, we now estimate Equation (3). This means that we include the different indicators of dairy prices, input intensification, and access to dairy buyers and services provided in the dairy value chain as additional sets of control variables in our original Equation (1). We do not include variables describing farmers' decision about the production and marketing of dairy (or agricultural) products, as these indicators are highly endogenous to the dependent variable of interest, productivity. The idea is that if there are mechanisms that explain the effect of urban proximity on dairy productivity, adding these indicators in the empirical estimation will reduce the magnitude of the direct effect of travel time on productivity, and potentially make the effect statistically insignificant. 
Table 6.2: Milk productivity and travel time to Addis Ababa, with increasing number of controls

\begin{tabular}{|c|c|c|c|c|c|c|}
\hline \multirow[b]{2}{*}{ Explanatory variables: } & \multicolumn{6}{|c|}{ Milk Productivity (liter per day per cow) } \\
\hline & (1) & $(2)$ & (3) & $(4)$ & (5) & (6) \\
\hline \multirow[t]{2}{*}{ Travel time to Addis Ababa (hours) } & $-0.77^{\star \star \star}$ & $-0.99 * \star \star$ & $-0.20^{\star}$ & -0.25 & $-0.42^{\star \star \star}$ & -0.09 \\
\hline & $(0.23)$ & $(0.22)$ & $(0.11)$ & $(0.20)$ & $(0.12)$ & $(0.13)$ \\
\hline \multirow[t]{2}{*}{ Milk price (ETB per liter) } & & 0.05 & & & & -0.02 \\
\hline & & $(0.19)$ & & & & $(0.07)$ \\
\hline \multirow[t]{2}{*}{ Butter price (ETB per kg) } & & 0.00 & & & & 0.00 \\
\hline & & $(0.00)$ & & & & $(0.00)$ \\
\hline \multirow[t]{2}{*}{ Cheese price (ETB per kg) } & & $-0.07^{\star \star \star}$ & & & & -0.00 \\
\hline & & $(0.03)$ & & & & $(0.02)$ \\
\hline \multirow[t]{2}{*}{ Artificial insemination (\%) } & & & $0.02^{\star * *}$ & & & $0.01^{* *}$ \\
\hline & & & $(0.00)$ & & & $(0.00)$ \\
\hline \multirow[t]{2}{*}{ Vaccination (\%) } & & & $0.00^{\star}$ & & & 0.00 \\
\hline & & & $(0.00)$ & & & $(0.00)$ \\
\hline \multirow[t]{2}{*}{ Crossbred (\% of cattle) } & & & $0.05^{\star \star \star}$ & & & $0.03^{\star * *}$ \\
\hline & & & $(0.01)$ & & & $(0.01)$ \\
\hline \multirow[t]{2}{*}{ Cows in milk production (number) } & & & $0.57^{\star \star \star}$ & & & $0.54^{* \star *}$ \\
\hline & & & $(0.11)$ & & & $(0.11)$ \\
\hline \multirow[t]{2}{*}{ Expenditure on feed (1,000 ETB) } & & & 0.01 & & & -0.02 \\
\hline & & & $(0.13)$ & & & $(0.11)$ \\
\hline \multirow[t]{2}{*}{ Dairy markets in the village (number) } & & & & -0.14 & & -0.01 \\
\hline & & & & $(0.23)$ & & $(0.17)$ \\
\hline \multirow[t]{2}{*}{ Milk processing company buying in village (no.) } & & & & $1.32^{\star \star \star}$ & & $0.67^{\star}$ \\
\hline & & & & $(0.43)$ & & $(0.37)$ \\
\hline \multirow[t]{2}{*}{ Liquid milk collector buying in village (number) } & & & & $1.10^{\star \star \star}$ & & $0.64^{\star *}$ \\
\hline & & & & $(0.29)$ & & $(0.32)$ \\
\hline \multirow[t]{2}{*}{ Traders active at dairy markets (number) } & & & & 0.01 & & 0.00 \\
\hline & & & & $(0.01)$ & & $(0.01)$ \\
\hline \multirow[t]{2}{*}{ Buyer provides training \& advice (\%) } & & & & & 0.01 & -0.01 \\
\hline & & & & & $(0.01)$ & $(0.01)$ \\
\hline \multirow[t]{2}{*}{ Buyer distributes inputs and credit (\%) } & & & & & $0.02^{\star}$ & 0.00 \\
\hline & & & & & $(0.01)$ & $(0.01)$ \\
\hline \multirow[t]{2}{*}{ Buyer provides services (\%) } & & & $1.46^{\star \star}$ & & $0.03^{\star \star *}$ & 0.00 \\
\hline & & & $(0.59)$ & & $(0.01)$ & $(0.00)$ \\
\hline \multirow[t]{2}{*}{ Constant } & $4.80^{\star \star \star}$ & $6.80^{\star \star \star}$ & 870 & $1.24^{\star *}$ & $2.42^{\star \star \star}$ & 0.69 \\
\hline & $(1.10)$ & $(2.30)$ & 0.597 & $(0.62)$ & $(0.52)$ & $(1.09)$ \\
\hline Observations & 870 & 870 & 870 & 839 & 839 & 839 \\
\hline R-squared & 0.215 & 0.254 & 0.597 & 0.480 & 0.332 & 0.650 \\
\hline
\end{tabular}

Note: In each cell, the number represents the regression coefficient of travel time on milk productivity from the IV estimation where in each column different sets of additional control variables are included: column (1) refers to the original Equation (1) with only the standard control variables $X$ included, column (2) refers to (1) with price vector P included, column (3) refers to (1) with the input application vector I included, column (4) refers to (1) with the vector of buyer access in W included, column (5) refers to (1) with service access vector in W included; column (6) refers to the full estimation of Equation (3). The number between brackets is the bootstrapped and kebele clustered standard error. ${ }^{* \star *} p<0.01,{ }^{* *} p<0.05,{ }^{*} p<0.1$.

Table 6.2 reports stepwise the regression coefficients of the effect of travel time on milk productivity. The first column is the estimation of Equation (1) with the original set of control variables, and the subsequent columns add additional sets of control variables as described in Equation (3). The second column adds dairy output prices (for milk, butter, and cheese) to the regression. The third column controls for the inputs used in dairy production, and is basically a (reduced form) milk production function. ${ }^{20}$ The fourth column adds the indicators of access to dairy

${ }^{20}$ We replace the application on fodder and industrial feed variables by the average (over 2-month interval) expenditure on feed (fodder and industrial), because the former is asked for the last week before the survey and, hence, might not capture complete usage. 
markets, i.e., the number of markets for processed dairy, the number of (liquid) milk processing companies, the number of individual milk collectors, and the number of traders active in the (largest) market for processed dairy products. The fifth panel includes indicators of services provided by buyers (training, inputs, credit, and other services). The final column includes all of the above sets of control variables.

The second column shows that milk and butter prices do not significantly affect milk productivity, but the price of cheese has a negative effect on productivity. However, this effect becomes insignificant in the full model (last column). This suggests that dairy production is only in a limited way affected by price incentives. ${ }^{21}$ The third column shows that when inputs into dairy production are controlled for, the effect of travel time becomes smaller but remains (weakly) significant. All variables that indicate a greater uptake of improved genetic material - the use of artificial insemination and the share of crossbred cows - as well as the number of cows in production (size effect) have a significant and substantial effect on liquid milk productivity. These effects remain robust when we include all controls in the last column.

More interestingly, the fourth column shows that when indicators of households' access to buyers within the value chain are included in the regression, the effect of travel time on milk productivity becomes insignificant. The effect mainly comes from the number of liquid milk processing companies and independent milk collectors active in village, as the two indicators of market activity for processed dairy products do not have a significant effect on milk productivity. This suggests that having access to processing companies, whether sourcing directly or sourcing indirectly through independent milk collectors, varies significantly with travel time (Table 6.1), and that it captures (some of) the effect of travel time on milk productivity (Table 6.2).

In the fifth column, the access of households to a buyer that distributes inputs and credit to clients, and the access of a buyer that provides other services (e.g., buying milk during fasting periods; medicine, veterinary services, or artificial insemination; and storage cans) has a significant effect on milk productivity. Including these service indicators also lowers the direct effect of travel time, but it makes the effect remains statistically significant.

In the final column, we bring all the controls into one regression. The direct effect of travel time becomes insignificant, and the effect of access to modern buyers of liquid milk remains to have a significant effect on productivity, although at a lower significance level. The effect of the services provided by buyers has no significant effect any more once we control for all potential mechanisms. Hence, it seems that the effect of travel time, and hence spatial location, mainly runs through access to higher value markets, i.e., buyers of liquid milk that serve modern processing companies. There is also some (weak) evidence that part of this comes from the services that these buyers provide to farmers and from input intensification. Taken all together, these results suggest that the better access to liquid milk value chains of farmers more closely located to Addis Ababa contributes to explaining the spatial heterogeneity in milk productivity in the commercial production zone around the capital. ${ }^{22}$

\section{CONCLUSIONS}

As urban demand drives the modernization of production systems in agricultural value chains, the location of farmers with respect to urban centers determines how well farmers can reap the benefits

\footnotetext{
21 This observation remains if we replace the imputed prices by self-reported values, village level or community price data

${ }^{22}$ We however warn for causal interpretation of this effect, as the indicators used to measure access to value chain buyers come from the community questionnaire, and hence are a less precise measure of individual access to the value chain. Further research should improve the measurement of (spatial) access to the value chain, by, for example, measuring the location of farmers with respect to modern processing companies.
} 
from growing markets and the value chains that serve these cities. In this paper, we look at the spatial heterogeneity in the production decisions and outcomes of dairy farmers that are located around the capital of Ethiopia, Addis Ababa. Dairy production in Ethiopia provides an interesting case study to examine spatial variation as demand for protein rich dairy products is growing fast, but transport of (fresh) dairy products requires the use of modern technologies. Data was therefore collected on $\mathbf{8 7 0}$ farmers located in the main two commercial production zones around Addis Ababa.

The paper shows that urban proximity - defined here as travel time from the farm of dairy producers to the capital - has a strong and significant effect on dairy productivity in Ethiopia. Using an instrumental variable estimation approach, where we use the travel time to Addis Ababa using a 'natural path' travelled by foot to instrument road network-based travel time, we show that each additional hour of travel time that farmers are located further away from the capital, reduces their milk productivity by 0.8 liter per cow per day or a reduction of 26 percent on average. This productivity pattern is reflected in the decisions that dairy producers take concerning what dairy product to produce, how many modern inputs that are applied in production, and how (and whether) they market their dairy production. Farmers that are closer to the capital are more likely to specialize in liquid milk production (as opposed to own processed dairy products), are more likely to sell liquid milk, and apply higher amounts of modern inputs into their dairy production.

We then try to shed a light on the potential mechanisms through which urban proximity affects dairy productivity. As is common in the spatial location literature, we control for spatial variety in prices that should capture transaction costs and differential consumer demand. However, our results suggest that the effect of travel time mainly runs through the access to 'modern' liquid milk value chains, even when we control for prices and input application. The value chain effect seems to run through the access to commercial liquid milk buyers that farmers located closer to Addis Ababa have, and possibly through the services that these buyers provide to farmers. The results of this paper thus provide empirical evidence that access to liquid milk value chains are an important determinant of dairy productivity, and that inclusion of producers in this value chain can have important implications for rural incomes and, hence, poverty. 


\section{REFERENCES}

AGRA (Alliance for a Green Revolution in Africa). 2019. Africa Agriculture Status Report: The Hidden Middle: A Quiet Revolution in the Private Sector Driving Agricultural Transformation (Issue 7). Nairobi, Kenya: Alliance for a Green Revolution in Africa (AGRA).

Amare, M., and B. Shiferaw. 2017. "Nonfarm Employment, Agricultural Intensification, and Productivity Change: Empirical Findings from Uganda." Agricultural Economics 48 (S1): 59-72. https://doi.org/10.1111/agec.12386.

Ayalew, W., A. Mohammed, and N. Enyew. 2015. "Milk Production Performance of Holstein Friesian Dairy Cows at Holetta Bull Dam Farm, Ethiopia." Livestock Research for Rural Development 27 (173). Accessed August 27, 2019. http://www.Irrd.org//rrd27/9/wond27173.html.

Berg, C.N., B. Blankespoor, and H. Selod. 2018. "Roads and Rural Development in Sub-Saharan Africa." The Journal of Development Studies 54 (5): 856-74. https://doi.org/10.1080/00220388.2018.1430772.

Binswanger-Mkhize, H.P., and S. Savastano. 2017. "Agricultural Intensification: The Status in Six African Countries." Food Policy 67 (February): 26-40. https://doi.org/10.1016/j.foodpol.2016.09.021.

Boserup, E., 1965. Conditions of Agricultural Growth. Aldine Publications, Chicago.

Chagwiza, C., R. Muradian, and R. Ruben. 2016. "Cooperative Membership and Dairy Performance among Smallholders in Ethiopia." Food Policy 59 (February): 165-73. https://doi.org/10.1016/i.foodpol.2016.01.008.

Chamberlin, J., and T.S. Jayne. 2013. "Unpacking the Meaning of 'Market Access': Evidence from Rural Kenya." World Development 41 (January): 245-64. https://doi.org/10.1016/i.worlddev.2012.06.004.

Christiaensen, L., and J. Vandercasteelen. 2019. "Earning More on the Farm." In Accelerating Poverty Reduction in Africa, edited by K. Beegle, and L. Christiaensen. Washington, D.C.: World Bank.

Damania, R., C. Berg, J. Russ, A.F. Barra, J. Nash, and R. Ali. 2017. "Agricultural Technology Choice and Transport." American Journal of Agricultural Economics 99 (1): 265-84. https://doi.org/10.1093/ajae/aav073.

Davis, B., S.D. Giuseppe, and A. Zezza. 2017. "Are African Households (Not) Leaving Agriculture? Patterns of Households' Income Sources in Rural Sub-Saharan Africa." Food Policy 67 (February): 153-74. https://doi.org/10.1016/i.foodpol.2016.09.018.

Dorosh, P., H.G. Wang, L. You, and E. Schmidt. 2012. "Road Connectivity, Population, and Crop Production in Sub-Saharan Africa." Agricultural Economics 43 (1): 89-103. https://doi.org/10.1111/j.15740862.2011.00567.X.

Duncan, A.J., N. Teufel, K. Mekonnen, V.K. Singh, A. Bitew, and B. Gebremedhin. 2013. "Dairy Intensification in Developing Countries: Effects of Market Quality on Farm-Level Feeding and Breeding Practices." Animal 7 (12): 2054-62. https://doi.org/10.1017/S1751731113001602.

Fafchamps, M., and F. Shilpi. 2003. "The Spatial Division of Labour in Nepal." Journal of Development Studies 39 (6): 23-66. https://doi.org/10.1080/00220380312331293577.

Freeman, H. 1998. "Credit Constraints and Smallholder Dairy Production in the East African Highlands: Application of a Switching Regression Model." Agricultural Economics 19 (1-2): 33-44. https://doi.org/10.1016/S0169-5150(98)00044-9.

Gollin, D., R. Jedwab, and D. Vollrath. 2016. "Urbanization with and without Industrialization." Journal of Economic Growth 21 (1): 35-70. https://doi.org/10.1007/s10887-015-9121-4.

Hirvonen, K., J. Hoddinott, B. Minten, and D. Stifel. 2017. "Children's Diets, Nutrition Knowledge, and Access to Markets." World Development 95 (July): 303-15. https://doi.org/10.1016/..worlddev.2017.02.031.

limi, A., L. You, and U. Wood-Sichra. 2018. Crop Production, Transport Infrastructure, and Agrobusiness Nexus: Evidence from Madagascar. Policy Research Working Papers WPS8486. Washington DC: The World Bank. https://doi.org/10.1596/1813-9450-8486.

Janssen, E., and J. Swinnen. 2017. "Technology Adoption and Value Chains in Developing Countries: Evidence from Dairy in India." Food Policy 83 (2019): 327-336. https://doi.org/10.1016/j.foodpol.2017.08.005.

Kebebe, E. 2019. "Bridging Technology Adoption Gaps in Livestock Sector in Ethiopia: A Innovation System Perspective." Technology in Society 57 (May): 30-37. https://doi.org/10.1016/j.techsoc.2018.12.002.

Kilelu, C., L. Klerkx, A. Omore, I. Baltenweck, C. Leeuwis, and J. Githinji. 2017. "Value Chain Upgrading and the Inclusion of Smallholders in Markets: Reflections on Contributions of Multi-Stakeholder Processes in Dairy Development in Tanzania." The European Journal of Development Research 29 (5): 11021121. https://doi.org/10.1057/s41287-016-0074-z. 
Lie, H., K.M. Rich, R. van der Hoek, and K. Dizyee. 2018. "An Empirical Evaluation of Policy Options for Inclusive Dairy Value Chain Development in Nicaragua: A System Dynamics Approach." Agricultural Systems 164 (July): 193-222. https://doi.org/10.1016/j.agsy.2018.03.008.

Minten, B., Y. Habte, S. Tamru, and A. Tesfaye. 2018. "Transforming Agri-Food Systems in Ethiopia: Evidence from the Dairy Sector." ESSP Working Paper 129. Addis Ababa: International Food Policy Research Institute. http://ebrary.ifpri.org/cdm/ref/collection/p15738coll2/id/133020.

Nakamura, S., T. Bundervoet, and M. Nuru. 2019. "Rural Roads, Poverty, and Resilience: Evidence from Ethiopia." WPS8800. Washington DC: The World Bank. http://documents.worldbank.org/curated/en/220781554130465463/Rural-Roads-Poverty-andResilience-Evidence-from-Ethiopia.

OECD/FAO. 2016. OECD-FAO Agricultural Outlook 2016-2025. OECD Publishing, Paris. http://dx.doi.org/10.1787/agr outlook-2016-en.

Samuelson, P. 1952. "The transfer problem and transport costs." Economic Journal 64: 264- 89.

Schmidt, E., P. Dorosh, M.K. Jemal, and J. Smart. 2018. Ethiopia's Spatial and Structural Transformation. ESSP Working Paper 119. Addis Ababa: International Food Policy Research Institute.

Steinhübel, L. 2018. "Somewhere in between Towns, Markets, and Neighbors Agricultural Transition in the Rural-Urban Interface of Bangalore, India." 256. Courant Research Centre: Poverty, Equity and GrowthDiscussion Papers.

Stifel, D., and B. Minten. 2017. "Market Access, Well-Being, and Nutrition: Evidence from Ethiopia." World Development 90 (February): 229-41. https://doi.org/10.1016/i.worlddev.2016.09.009.

Swinnen, J., and R. Kuijpers. 2019. "Value Chain Innovations for Technology Transfer in Developing and Emerging Economies: Conceptual Issues, Typology, and Policy Implications." Food Policy 83 (February): 298-309. https://doi.org/10.1016/j.foodpol.2017.07.013.

Vandercasteelen, J., S.T. Beyene, B. Minten, and J. Swinnen. 2018a. "Cities and Agricultural Transformation in Africa: Evidence from Ethiopia." World Development 105 (May): 383-99. https://doi.org/10.1016/j.worlddev.2017.10.032.

Vandercasteelen, J., S.T. Beyene, B. Minten, and J. Swinnen. 2018b. "Big Cities, Small Towns, and Poor Farmers: Evidence from Ethiopia." World Development 106 (June): 393-406. https://doi.org/10.1016/j.worlddev.2018.03.006.

Vandevelde, S., and D. Eline. 2019. "Fasting, Feasts and Food: Dairy Consumption and Value Chains in Ethiopia." Mimeo.

Weiss, D.J., A. Nelson, H.S. Gibson, W. Temperley, S. Peedell, A. Lieber, M. Hancher, et al. 2018. "A Global Map of Travel Time to Cities to Assess Inequalities in Accessibility in 2015." Nature 553 (7688): 33336. https://doi.org/10.1038/nature25181. 


\section{Appendix 1: Definitions of main variables used}

\section{Definitions of variables coming from the self-reported survey data}

\begin{tabular}{|c|c|c|}
\hline Name & Unit & Definition \\
\hline \multicolumn{3}{|c|}{ DAIRY PRODUCTION INDICATORS } \\
\hline Raw milk production - daily & Liter per day & $\begin{array}{l}\text { Daily production of raw milk (average of 2-month interval daily production } \\
\text { in the last year) }\end{array}$ \\
\hline $\begin{array}{l}\text { Raw milk productivity per } \\
\text { cow }\end{array}$ & $\begin{array}{l}\text { Liter per day } \\
\text { per cow }\end{array}$ & $\begin{array}{l}\text { Daily productivity, i.e., daily production of raw milk divided by the number } \\
\text { of cows in production }\end{array}$ \\
\hline $\begin{array}{l}\text { Raw milk production - } \\
\text { monthly }\end{array}$ & $\begin{array}{l}\text { Liter per } \\
\text { month }\end{array}$ & $\begin{array}{l}\text { Total quantity of raw milk produced in the last months, i.e., daily raw milk } \\
\text { production times the number of days that the cow was active in milk } \\
\text { production }\end{array}$ \\
\hline Liquid milk production & Liter & $\begin{array}{l}\text { Quantity of raw milk that is used as liquid milk (i.e., milk as end product) in } \\
\text { the last month }\end{array}$ \\
\hline Processed dairy production & $\begin{array}{l}\text { Liter - milk } \\
\text { equivalent }\end{array}$ & $\begin{array}{l}\text { Total quantity of yoghurt, butter, baadu, and cheese produced in the last } \\
\text { month, expressed in milk equivalents }\end{array}$ \\
\hline Produced liquid milk only & $\%$ & Share of households that produced only liquid milk \\
\hline $\begin{array}{l}\text { Produced processed dairy } \\
\text { only }\end{array}$ & $\%$ & Share of households that produced only processed dairy products \\
\hline $\begin{array}{l}\text { Produced both milk and } \\
\text { processed dairy }\end{array}$ & $\%$ & $\begin{array}{l}\text { Share of households that produced both liquid milk and processed dairy } \\
\text { products }\end{array}$ \\
\hline \multicolumn{3}{|r|}{ OUTPUT AND INPUT PRICES } \\
\hline Butter price & ETB per kg & $\begin{array}{l}\text { Average (if multiple transactions) of self-reported price received for the } \\
\text { sales of butter in the last month }\end{array}$ \\
\hline Cheese price & ETB per kg & $\begin{array}{l}\text { Average (if multiple transactions) of self-reported price received for the } \\
\text { sales of cheese in the last month }\end{array}$ \\
\hline Milk price & ETB per liter & $\begin{array}{l}\text { Average (if multiple transactions) of self-reported price received for the } \\
\text { sales of liquid milk in the last month }\end{array}$ \\
\hline Crossbred cow price & $\begin{array}{l}1,000 \mathrm{ETB} \\
\text { per cow }\end{array}$ & Self-reported price paid for the purchase of cows (if any) \\
\hline Local cow price & $\begin{array}{l}1,000 \text { ETB } \\
\text { per cow }\end{array}$ & $\begin{array}{l}\text { Village level price for the purchase of a local cow (from community } \\
\text { questionnaire) }\end{array}$ \\
\hline Artificial Insemination price & $\begin{array}{l}\text { ETB per } \\
\text { service }\end{array}$ & $\begin{array}{l}\text { Village level price for Artificial Insemination service (from community } \\
\text { questionnaire) }\end{array}$ \\
\hline Vaccination price & $\begin{array}{l}\text { ETB per } \\
\text { service }\end{array}$ & Village level price for vaccination service (from community questionnaire) \\
\hline \multicolumn{3}{|r|}{ DAIRY CATTLE OWNERSHIP } \\
\hline Cattle herd size & Number & $\begin{array}{l}\text { Quantity of cattle owned by household, including any type of cows (calved } \\
>\text { once), heifer ( }>1 \text { year not calved), female calves }(<1 \text { year), bulls }(>3 \\
\text { years), oxen ( }>3 \text { years), immature males ( } 1-3 \text { years), and male calves } \\
\text { ( }<1 \text { year) }\end{array}$ \\
\hline Cow herd size & Number & $\begin{array}{l}\text { Quantity of cows (calved > once) owned by household, including any type } \\
\text { of cows }\end{array}$ \\
\hline Cow herd value & USD & $\begin{array}{l}\text { Value of total cow herd size (sum of quantity times price for each type of } \\
\text { cow) }\end{array}$ \\
\hline Crossbred cow herd size & Number & Quantity of crossbred cows owned \\
\hline Crossbred cow herd value & USD & $\begin{array}{l}\text { Value of crossbred cow herd size (quantity times price for each crossbred } \\
\text { cows) }\end{array}$ \\
\hline Local cow herd size & Number & Quantity of local cows owned \\
\hline Local cow herd value & USD & $\begin{array}{l}\text { Value of local cow herd size (quantity times price for each crossbred } \\
\text { cows) }\end{array}$ \\
\hline Cows in milk production & Number & $\begin{array}{l}\text { Quantity of cows (local and crossbred) that are in production for the } \\
\text { reference period asked ( } 2 \text { monthly interval) }\end{array}$ \\
\hline Crossbred share & $\%$ & Share of cows owned by household that is crossbred \\
\hline Any crossbred cow & $\%$ & Probability that the household has at least one crossbred cow in herd \\
\hline \multicolumn{3}{|c|}{ INPUT USAGE AND EXPENDITURE IN DAIRY } \\
\hline Artificial insemination usage & $\%$ & $\begin{array}{l}\text { Share of households that use artificial insemination as main breeding } \\
\text { method }\end{array}$ \\
\hline
\end{tabular}




\begin{tabular}{|c|c|c|}
\hline Artificial insemination cost & USD & Price of service for artificial insemination \\
\hline Veterinary service usage & $\%$ & $\begin{array}{l}\text { Share of households that have used any veterinary service during the last } \\
12 \text { months }\end{array}$ \\
\hline Veterinary service cost & USD & Expenditure on veterinary service in the last 12 months \\
\hline Vaccination usage & $\%$ & Share of households that used vaccination during the last month \\
\hline Medicine usage & $\%$ & Share of households that used medicine during the last 12 months \\
\hline Medicine cost & USD & Expenditure on medicine in the last 12 months \\
\hline Fodder usage & Kg per day & Daily quantity of fodder used by the household as feed in the last week \\
\hline Fodder cost & USD & Expenditure on fodder feed in the last month \\
\hline Industrial feed usage & Kg per day & Daily quantity of industrial feed used by the household in the last week \\
\hline Industrial feed cost & USD & Expenditure on industrial feed in the last month \\
\hline Feed cost & 1,000 ETB & $\begin{array}{l}\text { Expenditure on fodder and industrial feed, averaged over } 2 \text { monthly } \\
\text { interval period }\end{array}$ \\
\hline \multicolumn{3}{|c|}{ HOUSEHOLD INCOME CHARACTERISTICS } \\
\hline Total household income & USD & $\begin{array}{l}\text { Sum of crop and dairy production value, value of other agricultural } \\
\text { income, and income from non-agricultural activities }\end{array}$ \\
\hline \multirow[t]{2}{*}{ Value of crop production } & USD & Sum of crop output quantity times market price for each crop type \\
\hline & $\%$ & Share of crop production value in total household income \\
\hline \multirow[t]{2}{*}{ Value of dairy production } & USD & Sum of dairy output quantity times market price for each dairy output type \\
\hline & $\%$ & Share of dairy production value in total household income \\
\hline \multirow[t]{2}{*}{$\begin{array}{l}\text { Value of other agricultural } \\
\text { income }\end{array}$} & USD & $\begin{array}{l}\text { Sum of rental income, income from livestock and livestock products other } \\
\text { than animals and dairy products, income from grasses and trees, and } \\
\text { other agricultural income }\end{array}$ \\
\hline & $\%$ & Share of other agricultural income in total household income \\
\hline \multirow[t]{2}{*}{ Non-agricultural income } & USD & Sum of wage income, non-farm enterprise income and remittances \\
\hline & $\%$ & Share of non-agricultural income in total household income \\
\hline \multirow[t]{2}{*}{ Value of milk production } & USD & Value of milk production used as end product \\
\hline & $\%$ & Contribution of milk production (as end product) to dairy production value \\
\hline \multirow[t]{2}{*}{ Value of butter production } & USD & Value of processed butter \\
\hline & $\%$ & Contribution of butter production to dairy production value \\
\hline \multirow[t]{2}{*}{ Value of cheese production } & USD & Value of processed cheese \\
\hline & $\%$ & Contribution of cheese production to dairy production value \\
\hline
\end{tabular}

\section{Definition of the travel time indicators}

In the paper, we make use of two travel time indicators, one following the existing road network, and a second following the natural features of the Ethiopian landscape. For the former, we created a digital map of the road network based on road segment data made available by the Ethiopian Road Authority.

We measure the travel time from the farm of each household to the central market place of Addis Ababa using the road network as the combination of two travel times. First, we measure the walking time from the farm to the nearest road segment that features on the digital map used. We assume straight-line movement and that transport happens on foot with a walking speed of $4.5 \mathrm{~km}$ per hour. Second, we measure the travel time from the household's nearest road segment to the market in Addis Ababa using the existing road network. To measure this travel time, we assume that households sell to traders, who travel over the existing road network to Addis Ababa. We assume that traders transport the milk (or dairy product) using motorized vehicles and are able to travel at the maximum allowed speed. To take into account that driving speed depends on road quality, we amended different travel speeds to the road segment data based on information on road quality, which is available in the Ethiopian Road Authority data. ${ }^{23}$ Travel times over the road network were

${ }^{23}$ Following Weiss et al. (2018) and Schmidt et al. (2018) we assign the following travel speeds to different roads: $90 \mathrm{~km} / \mathrm{h}$ for asphalt roads, $60 \mathrm{~km} / \mathrm{h}$ for major gravel roads, $30 \mathrm{~km} / \mathrm{h}$ for minor gravel roads, and $10 \mathrm{~km} / \mathrm{h}$ for earth tracks. 
then calculated for each household using the 'closest facility layer' toolbox in ArcGIS with Addis Ababa as the end destination.

We also measure the time it would take a farmer to walk from their farm to the central market of Addis Ababa using the most efficient walking path, i.e., shortest in walking time on foot. This 'natural path' does not follow the existing road networks, but the path through the actual terrain and other geographic conditions that minimizes the walking cost (time) to Addis Ababa. To calculate this walking time, we follow the methodology of Vandercasteelen et al. (2018b), but make use of the refined methodology outlined by Weiss et al. (2018) who measured the travel time to the nearest urban city. ${ }^{24}$ In ArcGIS, a 'friction layer' was constructed which is basically a raster of pixels each representing one square kilometer of land area for the study area around Addis Ababa. Each pixel is then assigned the time it takes a human to cross the pixel on foot, where we account for the effects of land use and other characteristics of the pixel on the time required to cross it on foot. To do so, we first assign to each pixel a travel speed depending on the (digitalized) type of land use category the pixel belongs to following the classification of travel speeds in Weiss et al. (2018). Then, we calculate adjustment factors that take into account that walking through the pixel might occur at a slower speed because of the geography of the pixel, due to factors like slope, elevation, or the occurrence of natural barriers, such as lakes or rivers. The travel time to cross a pixel is then calculated as the travel speed assigned to the pixel multiplied by the adjustment factors. Finally, the ArcGIS toolbox 'least cost path' was used to calculate the accumulated walking time from the location of the farm to the central market in Addis Ababa.

\footnotetext{
${ }^{24}$ However, in contrast to Weiss et al. (2018), we do not incorporate transport over roads, as we specifically want to use in our analysis the natural path cost of movement on foot to instrument for movement using vehicles. The main difference with the original methodology is that waterbodies (i.e., rivers and lakes) are considered as an obstacle to movement rather than a means of transport. Following Schmidt et al. (2018) we assume that movement over lakes or rivers can be at best $1.0 \mathrm{~km} / \mathrm{h}$, assuming an average travel speed of 5.0 $\mathrm{km} / \mathrm{h}$ on non-water bodies.
} 


\section{Appendix 2: Detailed regression results}

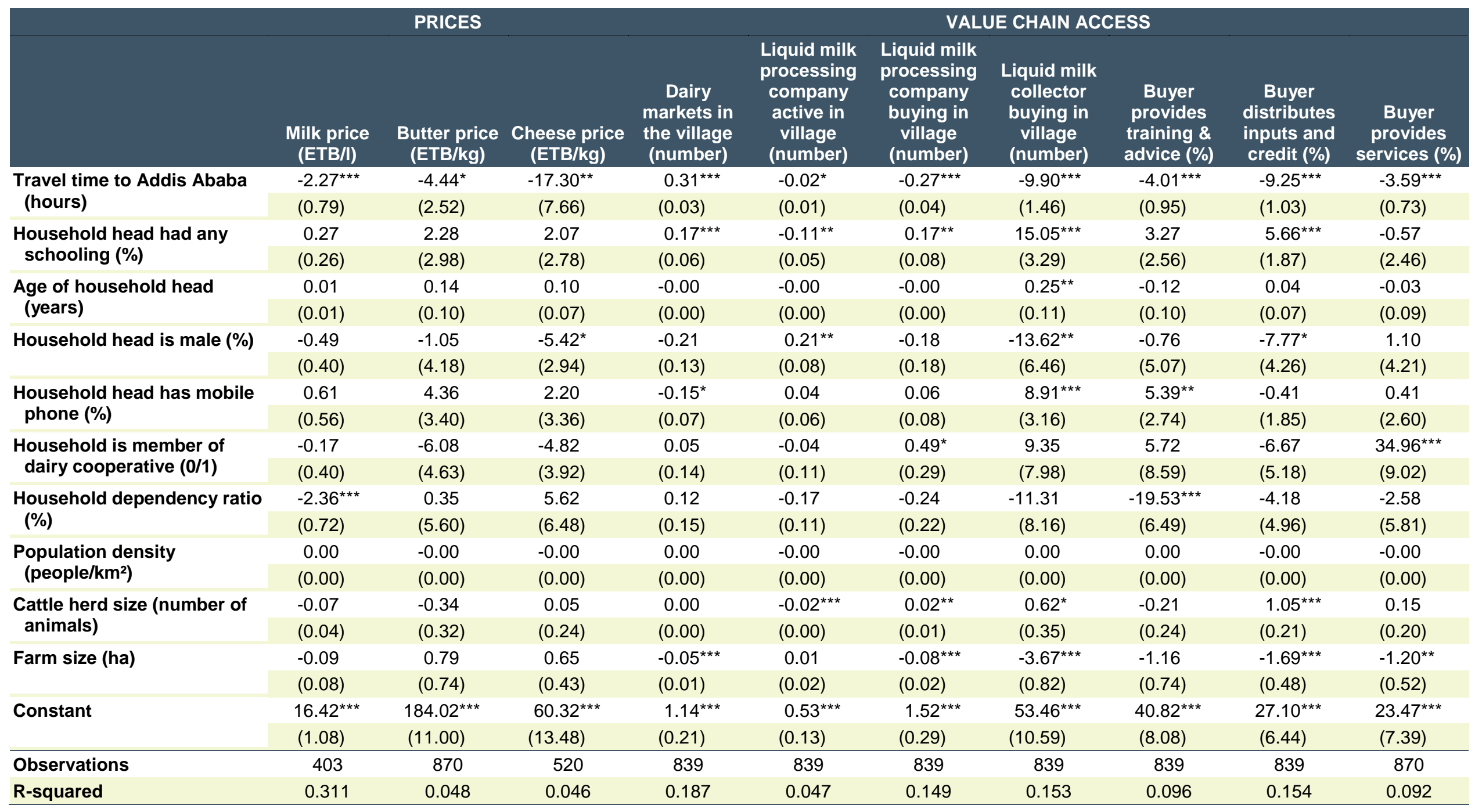

Source: Authors.

Note: In each cell, the number represents the regression coefficient of travel time on milk productivity from the IV estimation, while the number in parentheses is the bootstrapped and kebele clustered standard error. ${ }^{* \star \star} p<0.01,{ }^{* \star} p<0.05,{ }^{*} p<0.1$. 


\begin{tabular}{|c|c|c|c|c|c|c|c|c|c|}
\hline & \multicolumn{9}{|c|}{ INPUT DUMMIES OR APPLICATION } \\
\hline & $\begin{array}{l}\text { Crossbred } \\
\text { (\% of cattle) }\end{array}$ & $\begin{array}{l}\text { Crossbred } \\
\text { (\% owning) }\end{array}$ & $\begin{array}{l}\text { Cows in milk } \\
\text { production } \\
\text { (number) }\end{array}$ & $\begin{array}{c}\text { Artificial } \\
\text { insemination } \\
(\%)\end{array}$ & $\begin{array}{l}\text { Veterinary } \\
\text { service (\% in } \\
12 \text { months) }\end{array}$ & $\begin{array}{c}\text { Vaccination } \\
(\%)\end{array}$ & $\begin{array}{l}\text { Medicine } \\
\text { (\% } 12 \\
\text { months) }\end{array}$ & $\begin{array}{l}\text { Purchase of } \\
\text { fodder }(\mathbf{k g})\end{array}$ & $\begin{array}{l}\text { Purchase of } \\
\text { industrial } \\
\text { feed (kg) }\end{array}$ \\
\hline \multirow{2}{*}{$\begin{array}{l}\text { Travel time to Addis Ababa } \\
\text { (hours) }\end{array}$} & $-9.63^{\star \star \star}$ & 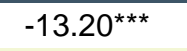 & $-0.12^{\star \star}$ & $-5.58^{\star \star \star}$ & $-3.68^{\star \star}$ & $-3.37^{\star \star}$ & 0.17 & -0.32 & $-1.41^{\star \star \star}$ \\
\hline & $(1.78)$ & $(2.06)$ & $(0.05)$ & $(1.65)$ & $(1.85)$ & $(1.51)$ & $(1.47)$ & $(0.24)$ & $(0.40)$ \\
\hline \multirow{2}{*}{$\begin{array}{l}\text { Household head had any } \\
\text { schooling (\%) }\end{array}$} & 1.47 & -2.43 & $0.20^{\star *}$ & $5.29^{\star \star}$ & -4.21 & -0.67 & -2.05 & $-2.83^{\star \star \star}$ & $2.37^{\star \star \star}$ \\
\hline & (3.31) & (3.71) & $(0.09)$ & $(2.64)$ & (3.57) & $(3.15)$ & (3.34) & $(0.71)$ & $(0.75)$ \\
\hline \multirow{2}{*}{$\begin{array}{l}\text { Age of household head } \\
\text { (years) }\end{array}$} & -0.01 & -0.08 & 0.00 & 0.13 & -0.19 & $-0.25^{\star}$ & $-0.20 * \star$ & $-0.05^{\star \star}$ & -0.01 \\
\hline & $(0.09)$ & $(0.13)$ & $(0.00)$ & $(0.08)$ & $(0.13)$ & $(0.13)$ & $(0.10)$ & $(0.02)$ & $(0.03)$ \\
\hline \multirow[t]{2}{*}{ Household head is male (\%) } & -0.26 & 8.75 & -0.10 & -8.25 & 6.10 & 8.14 & 6.80 & $1.69 \star \star$ & 0.01 \\
\hline & (5.79) & $(6.27)$ & $(0.11)$ & $(5.42)$ & (6.79) & (6.98) & (6.26) & $(0.77)$ & (1.27) \\
\hline \multirow{2}{*}{$\begin{array}{l}\text { Household head has mobile } \\
\text { phone (\%) }\end{array}$} & $6.68^{*}$ & 6.55 & 0.01 & $8.70^{\star \star \star}$ & 4.45 & 2.33 & 1.47 & $1.24^{\star *}$ & $2.54^{\star \star \star}$ \\
\hline & (3.99) & $(4.90)$ & $(0.08)$ & $(3.24)$ & $(4.95)$ & $(2.71)$ & (3.52) & $(0.57)$ & $(0.82)$ \\
\hline \multirow{2}{*}{$\begin{array}{l}\text { Household is member of } \\
\text { dairy cooperative }(0 / 1)\end{array}$} & $23.25^{\star \star \star}$ & $22.43^{\star \star \star}$ & 0.14 & $20.83^{\star \star \star}$ & $13.74^{\star *}$ & 1.06 & 5.23 & $2.96^{\star \star}$ & $5.13^{\star \star}$ \\
\hline & (6.39) & $(5.88)$ & $(0.17)$ & $(6.81)$ & $(6.41)$ & (7.54) & (6.16) & $(1.49)$ & $(2.21)$ \\
\hline \multirow{2}{*}{$\begin{array}{l}\text { Household dependency ratio } \\
\text { (\%) }\end{array}$} & -11.23 & -11.88 & 0.04 & $-20.44^{\star \star}$ & $-21.58^{\star \star \star}$ & $-16.03^{*}$ & -3.94 & -2.09 & $-6.56^{\star \star}$ \\
\hline & (7.68) & (7.59) & $(0.15)$ & (8.06) & $(6.79)$ & (8.47) & (7.05) & (1.29) & $(2.94)$ \\
\hline \multirow{2}{*}{$\begin{array}{l}\text { Population density } \\
(\text { people/km²) }\end{array}$} & 0.00 & 0.00 & 0.00 & 0.00 & -0.00 & 0.00 & 0.00 & -0.00 & -0.00 \\
\hline & $(0.00)$ & $(0.00)$ & $(0.00)$ & $(0.00)$ & $(0.00)$ & $(0.00)$ & $(0.00)$ & $(0.00)$ & $(0.00)$ \\
\hline \multirow{2}{*}{$\begin{array}{l}\text { Cattle herd size (number of } \\
\text { animals) }\end{array}$} & 0.23 & $0.90^{\star \star}$ & $0.17^{\star \star \star}$ & -0.14 & $0.53^{*}$ & $0.66^{\star *}$ & 0.51 & 0.10 & $0.28^{\star \star}$ \\
\hline & $(0.35)$ & $(0.43)$ & $(0.02)$ & $(0.36)$ & $(0.32)$ & $(0.29)$ & $(0.33)$ & $(0.07)$ & $(0.14)$ \\
\hline \multirow[t]{2}{*}{ Farm size (ha) } & $-2.70^{\star \star \star}$ & -1.66 & $-0.07^{\star}$ & $-1.96^{\star \star}$ & 1.09 & $1.01^{*}$ & 0.78 & 0.16 & $-0.66^{\star \star}$ \\
\hline & $(0.96)$ & $(1.13)$ & $(0.04)$ & $(0.89)$ & $(0.79)$ & $(0.57)$ & $(0.68)$ & $(0.17)$ & $(0.27)$ \\
\hline \multirow[t]{2}{*}{ Constant } & $55.04^{\star \star \star}$ & $66.73^{\star \star \star}$ & 0.22 & $34.36^{\star \star \star}$ & $76.96^{\star \star \star}$ & 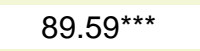 & $78.40 * \star \star$ & $6.45^{\star \star \star}$ & $8.35^{\star \star \star}$ \\
\hline & $(12.17)$ & $(14.31)$ & (0.19) & $(9.73)$ & $(11.11)$ & $(10.97)$ & $(9.64)$ & (1.89) & $(2.20)$ \\
\hline Observations & 870 & 870 & 870 & 870 & 870 & 870 & 870 & 870 & 870 \\
\hline R-squared & 0.226 & 0.213 & 0.477 & 0.157 & 0.043 & 0.055 & 0.018 & 0.040 & 0.100 \\
\hline
\end{tabular}

Note: In each cell, the number represents the regression coefficient of travel time on milk productivity from the IV estimation, while the number in parentheses is the bootstrapped and kebele clustered standard error. ${ }^{* \star *} p<0.01,{ }^{* *} p<0.05,{ }^{*} p<0.1$. 


\begin{tabular}{|c|c|c|c|c|c|c|c|c|c|c|c|c|}
\hline & \multicolumn{6}{|c|}{ INPUT EXPENDITURE } & \multicolumn{6}{|c|}{ PRODUCTION DECISION } \\
\hline & $\begin{array}{l}\text { Cattle value } \\
\text { (USD) }\end{array}$ & $\begin{array}{c}\text { Artificial } \\
\text { insemin- } \\
\text { ation (USD) }\end{array}$ & $\begin{array}{l}\text { Medicine } \\
\text { (USD in last } \\
\text { month) }\end{array}$ & $\begin{array}{l}\text { Veterinary } \\
\text { service } \\
\text { (USD) }\end{array}$ & $\begin{array}{l}\text { Purchase } \\
\text { of fodder } \\
\text { (USD) }\end{array}$ & $\begin{array}{c}\text { Purchase } \\
\text { of } \\
\text { industrial } \\
\text { feed (USD) }\end{array}$ & $\begin{array}{c}\text { Dairy value } \\
\text { (\% HH } \\
\text { income) }\end{array}$ & $\begin{array}{c}\text { Crop value } \\
\text { (\% HH } \\
\text { income) }\end{array}$ & $\begin{array}{l}\text { Other } \\
\text { agricultural } \\
\text { income (\% } \\
\text { HH income) }\end{array}$ & $\begin{array}{c}\text { Non- } \\
\text { agricultural } \\
\text { income (\% } \\
\text { HH income) }\end{array}$ & $\begin{array}{l}\text { Household } \\
\text { producing } \\
\text { milk only } \\
(\%)\end{array}$ & $\begin{array}{c}\text { Household } \\
\text { producing } \\
\text { processed } \\
\text { dairy only } \\
\text { (\%) }\end{array}$ \\
\hline \multirow{2}{*}{$\begin{array}{l}\text { Travel time Addis } \\
\text { Ababa (hours) }\end{array}$} & $-483.27^{\star \star \star}$ & $-0.18^{\star \star}$ & 0.10 & 0.09 & $-10.28^{\star \star}$ & $-17.56^{\star \star}$ & $-5.67^{\star \star \star}$ & $7.55^{\star \star \star}$ & -0.74 & $-1.15^{\star}$ & $-5.38^{\star}$ & -0.05 \\
\hline & $(149.07)$ & $(0.08)$ & $(0.59)$ & $(0.17)$ & $(5.17)$ & $(6.96)$ & $(1.78)$ & $(2.16)$ & $(0.64)$ & $(0.68)$ & $(2.91)$ & $(2.28)$ \\
\hline \multirow{2}{*}{$\begin{array}{l}\text { Household head had } \\
\text { any schooling (\%) }\end{array}$} & $497.30^{* *}$ & $0.29 * *$ & $2.64^{\star \star}$ & -0.07 & $12.08^{\star}$ & $20.41^{\star *}$ & $2.93^{*}$ & $-6.65^{\star \star \star}$ & $2.47^{\star \star}$ & 1.25 & 0.18 & -2.56 \\
\hline & $(216.26)$ & $(0.14)$ & $(1.09)$ & $(0.26)$ & $(6.90)$ & $(8.77)$ & $(1.77)$ & $(2.21)$ & $(0.96)$ & $(1.15)$ & (3.78) & (3.01) \\
\hline \multirow{2}{*}{$\begin{array}{l}\text { Age of household } \\
\text { head (years) }\end{array}$} & -1.26 & 0.01 & 0.02 & -0.01 & $-0.35^{\star}$ & -0.31 & -0.01 & 0.08 & 0.03 & $-0.09 * \star$ & 0.14 & $0.43^{\star \star \star}$ \\
\hline & $(5.34)$ & $(0.00)$ & $(0.03)$ & $(0.01)$ & $(0.21)$ & $(0.19)$ & $(0.08)$ & $(0.07)$ & $(0.03)$ & $(0.04)$ & $(0.10)$ & $(0.13)$ \\
\hline \multirow{2}{*}{$\begin{array}{l}\text { Household head is } \\
\text { male (\%) }\end{array}$} & 48.59 & -0.03 & -1.91 & $0.48^{\star \star}$ & 3.61 & -5.25 & -4.14 & 4.59 & -2.00 & 1.55 & -2.48 & $-12.17^{\star}$ \\
\hline & (217.78) & (0.10) & $(1.84)$ & $(0.21)$ & $(5.74)$ & $(9.22)$ & (3.07) & (3.45) & $(1.46)$ & (1.58) & $(5.74)$ & (6.96) \\
\hline \multirow{2}{*}{$\begin{array}{l}\text { Household head has } \\
\text { mobile phone }(\%)\end{array}$} & 24.18 & 0.08 & 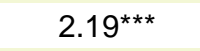 & $0.59^{\star}$ & -6.96 & 3.30 & -0.28 & -3.50 & 1.07 & $2.71^{\star}$ & $7.69 \star \star$ & $-8.70^{\star \star \star}$ \\
\hline & (136.88) & $(0.09)$ & $(0.51)$ & $(0.30)$ & $(6.66)$ & $(5.55)$ & $(2.48)$ & $(3.06)$ & $(0.89)$ & (1.43) & $(3.56)$ & $(2.96)$ \\
\hline \multirow{2}{*}{$\begin{array}{l}\mathrm{HH} \text { is member dairy } \\
\text { cooperative }(0 / 1)\end{array}$} & 991.38* & -0.04 & 3.24 & -0.08 & -8.08 & -4.24 & $8.74^{\star \star}$ & $-14.62^{\star \star \star}$ & -0.49 & $6.37^{\star}$ & 7.37 & $-9.33^{\star \star}$ \\
\hline & $(518.14)$ & $(0.25)$ & (3.22) & $(0.74)$ & $(16.48)$ & (17.94) & $(4.05)$ & $(3.50)$ & $(2.14)$ & $(3.25)$ & $(7.85)$ & $(4.75)$ \\
\hline \multirow{2}{*}{$\begin{array}{l}\text { Household depend- } \\
\text { ency ratio (\%) }\end{array}$} & $-1,101.60$ ** & -0.16 & -0.46 & -0.45 & $-23.98^{\star \star}$ & -38.25 & 1.08 & 2.00 & -0.45 & -2.63 & $-18.96^{\star \star \star}$ & -11.25 \\
\hline & $(481.10)$ & $(0.17)$ & $(1.80)$ & $(0.56)$ & (10.93) & (23.51) & $(4.56)$ & (5.11) & (2.04) & (2.58) & $(6.27)$ & (8.43) \\
\hline \multirow{2}{*}{$\begin{array}{l}\text { Population density } \\
\text { (people/km²) }\end{array}$} & -0.06 & -0.00 & 0.00 & -0.00 & -0.00 & -0.00 & -0.00 & 0.00 & -0.00 & 0.00 & 0.00 & -0.00 \\
\hline & (0.11) & $(0.00)$ & $(0.00)$ & $(0.00)$ & $(0.00)$ & $(0.00)$ & $(0.00)$ & $(0.00)$ & $(0.00)$ & $(0.00)$ & $(0.00)$ & $(0.00)$ \\
\hline \multirow{2}{*}{$\begin{array}{l}\text { Cattle herd size (no. } \\
\text { animals) }\end{array}$} & $184.81^{\star * *}$ & $0.05^{\star}$ & $0.70^{\star \star \star}$ & $0.11^{\star \star *}$ & 4.61 & $6.23^{\star \star}$ & $0.97^{\star \star \star}$ & $-0.60^{\star \star}$ & -0.10 & $-0.26^{\star \star}$ & -0.30 & 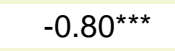 \\
\hline & $(62.60)$ & $(0.03)$ & $(0.23)$ & $(0.04)$ & (3.30) & (3.10) & $(0.22)$ & $(0.27)$ & $(0.07)$ & $(0.12)$ & $(0.37)$ & $(0.25)$ \\
\hline \multirow[t]{2}{*}{ Farm size (ha) } & $-282.49 * \star$ & $-0.13^{\star \star}$ & -0.63 & -0.10 & -8.30 & $-12.12^{\star \star}$ & 0.80 & $-1.58^{\star \star}$ & $0.84^{\star \star}$ & -0.06 & $-2.93^{\star \star \star}$ & $1.68^{\star \star}$ \\
\hline & $(119.37)$ & $(0.06)$ & $(0.43)$ & $(0.07)$ & $(5.18)$ & $(6.04)$ & $(0.70)$ & $(0.80)$ & $(0.33)$ & $(0.28)$ & $(0.98)$ & $(0.83)$ \\
\hline \multirow[t]{2}{*}{ Constant } & $1,130.17^{\star \star *}$ & 0.13 & -1.64 & 0.15 & $38.59 * \star \star$ & $63.52^{\star \star}$ & $50.57^{\star * *}$ & $31.66^{\star * *}$ & $5.56^{\star \star}$ & $12.21^{\star * *}$ & $38.20 * \star \star$ & $26.13^{\star \star}$ \\
\hline & $(365.67)$ & $(0.32)$ & (3.07) & $(0.83)$ & $(12.91)$ & $(27.52)$ & $(6.65)$ & $(8.23)$ & $(2.63)$ & $(4.05)$ & $(12.05)$ & $(12.32)$ \\
\hline Observations & 870 & 870 & 870 & 870 & 870 & 870 & 870 & 870 & 870 & 870 & 870 & 870 \\
\hline R-squared & 0.271 & 0.087 & 0.127 & 0.044 & 0.053 & 0.188 & 0.163 & 0.214 & 0.026 & 0.060 & 0.125 & 0.090 \\
\hline
\end{tabular}

Source: Authors.

Note: In each cell, the number represents the regression coefficient of travel time on milk productivity from the IV estimation, while the number in parentheses is the bootstrapped and kebele clustered standard error. ${ }^{\star * \star} p<0.01,{ }^{* *} p<0.05,{ }^{*} p<0.1$. 


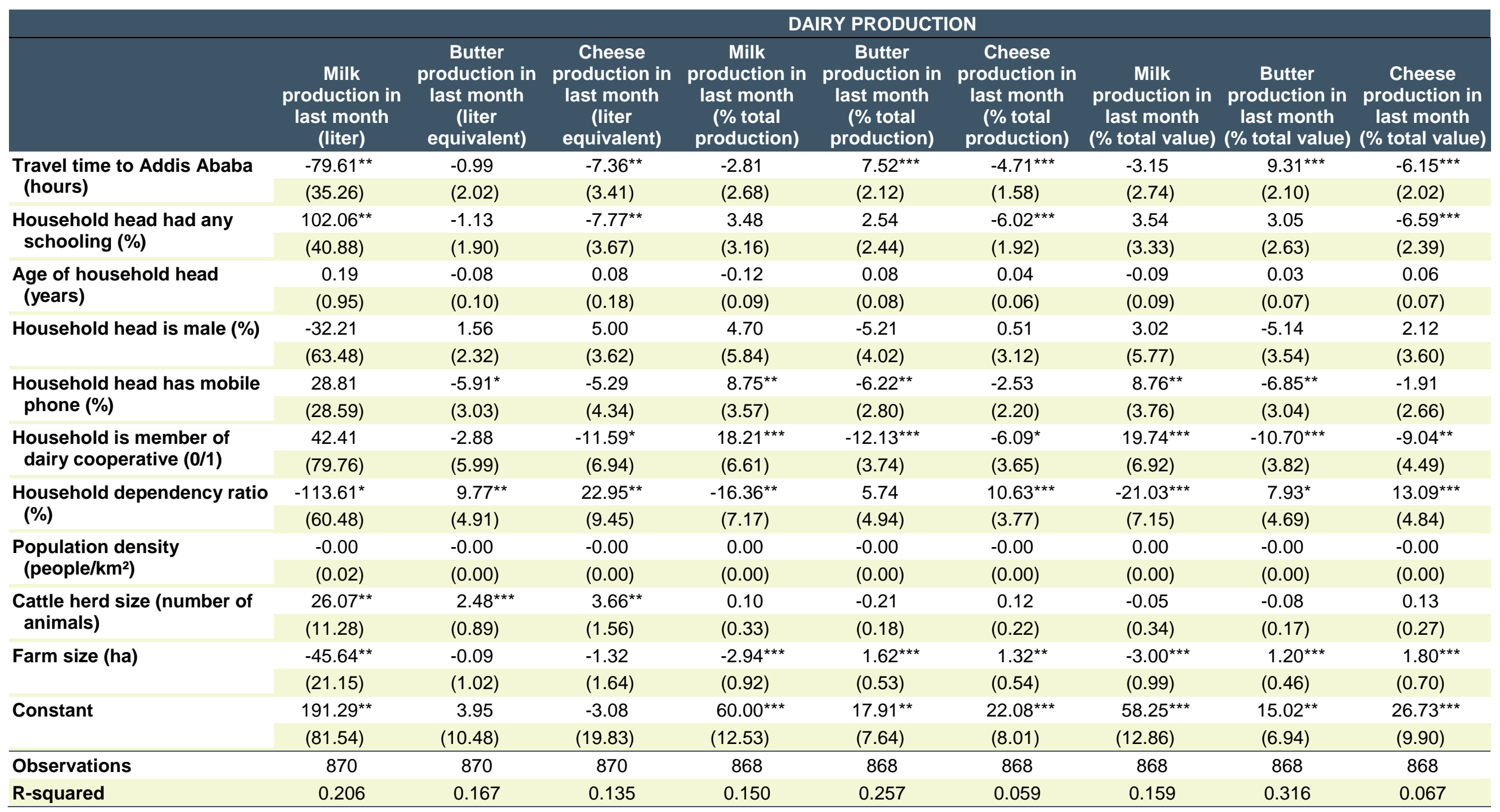

Source: Authors.

Note: In each cell, the number represents the regression coefficient of travel time on milk productivity from the IV estimation, while the number in parentheses is the bootstrapped and kebele clustered standard error. ${ }^{\star \star \star} p<0.01,{ }^{* *} p<0.05,{ }^{*} p<0.1$. 


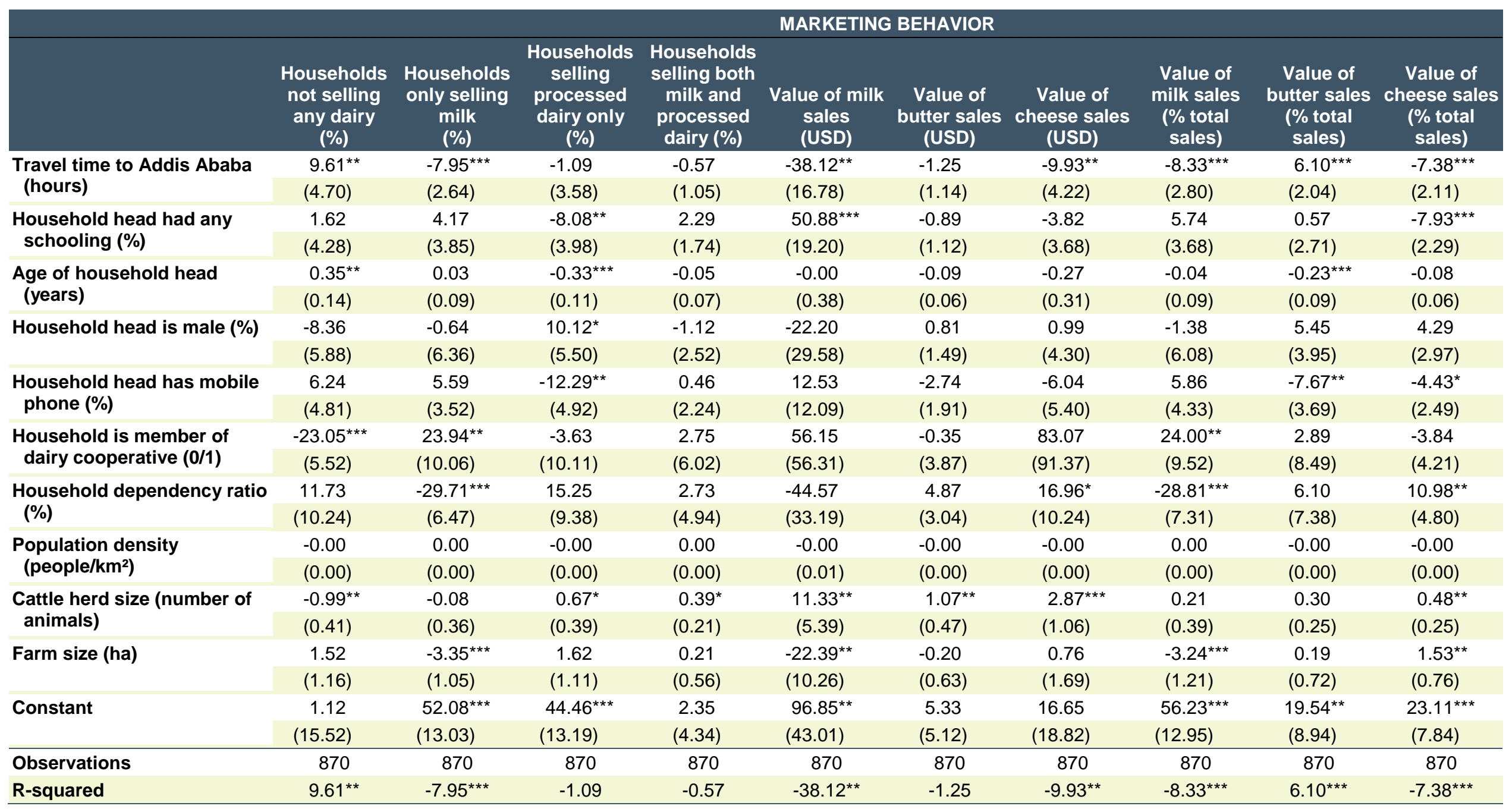

Source: Authors.

Note: In each cell, the number represents the regression coefficient of travel time on milk productivity from the IV estimation, while the number in parentheses is the bootstrapped and kebele clustered standard error. ${ }^{\star * \star} p<0.01,{ }^{* *} p<0.05,{ }^{*} p<0.1$. 


\section{ABOUT THE AUTHORS}

Joachim Vandercasteelen is a post-doctoral fellow at LICOS - Center for Institutions and Economic Performance, University of Leuven, Leuven, Belgium. Bart Minten is Program Leader of the Ethiopia Strategy Support Program (ESSP) and a Senior Research Fellow in the Development Strategy and Governance Division (DSGD) of the International Food Policy Research Institute (IFPRI), based in Addis Ababa. Seneshaw Tamru is a Collaborator in DSGD of IFPRI, based in Addis Ababa.

INTERNATIONAL FOOD POLICY RESEARCH INSTITUTE 1201 Eye St, NW | Washington, DC 20005 USA

T. +1-202-862-5600 | F. +1-202-862-5606

Email: ifpri@cgiar.org | www.ifpri.org | www.ifpri.info

IFPRI-ESSP ADDIS ABABA

P.O. Box 5689, Addis Ababa, Ethiopia

T. +251-11-617-2000 | F. +251-11-667-6923

Email: ifpri-essp@cgiar.org | http://essp.ifpri.info
POLICY STUDIES INSTITUTE

P.O. Box 2479, Addis Ababa, Ethiopia

T. +251.11-550-6066; +251-11-553-8633 | F. +251-11-550-5588 http://psi.gov.et/

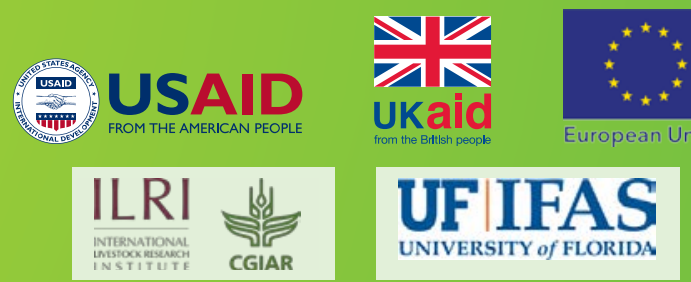

The Ethiopia Strategy Support Program (ESSP) is managed by the International Food Policy Research Institute (IFPRI); is jointly implemented with the Policy Studies Institute (PSI); and is financially supported by the United States Agency for International Development (USAID), the Department for International Development (DFID) of the government of the United Kingdom, and the European Union (EU). The research presented here was conducted as part of the CGIAR Research Program on Policies, Institutions, and Markets (PIM), which is led by IFPRI. This study was made possible by the generous support of the American people through USAID under the Feed the Future Innovation Lab for Livestock Systems (LSIL), which is implemented by the Institute of Food and Agricultural Sciences of the University of Florida in partnership with the International Livestock Research Institute (ILRI). LSIL is funded by the United States Agency for International Development (USAID) through a five-year Leader with Associates Cooperative Agreement Award No. AID-OAA-L-15-00003. This publication has been prepared as an output of ESSP and has not been independently peer reviewed. Any opinions expressed here belong to the author(s) and are not necessarily representative of or endorsed by IFPRI, PSI, USAID, DFID, EU, University of Florida, ILRI, PIM, or CGIAR. 